\title{
歯牙欠損後の両隣在歯および周囲組織の病理組織学的研究
}

\author{
九州歯科大学口腔外科学教室第 1 講座（指導：山田辰敬教授） \\ 九州歯科大学口膑病理学講坐(指導：上野正康教授）
}

栄 井 貞 雄

昭和55年 5 月 30 日受付

\section{An Experimental Study of Changes in Neighboring Teeth and Periodontal Tissues after a Tooth Loss}

\author{
Sadao Iwai
}

First Department of Oral Surgery (Director : Prof. Nagayoshi Yamada)

Department of Oral Pathology (Director : Prof. Masayasu Ueno)

Kyushu Dental College, Kitakyushu, Japan

A loss of tooth caused by teeth and periodontal diseases is frequently encountered in the daily clinical work. The two neighboring teeth and periodontal tissues, in coping with healing of tooth extraction wound and functional changes, show changes as reactions of the affected region to such a tooth loss.

Detailed reports on experimental studes of healing process of tooth extraction wound, changes in the form of alveolar ridge, and shifts of the two neighboring teeth after a tooth loss are available. However, pathohistological studies of displacement process of the two neighboring teeth are few. Changes in periodontal ligaments, in particular, remain unaccounted for.

Monkeys (macaca irus) were used for the present study. The lower first molar were extracted and changes in the periodontal tissues of the two neighboring teeth were investigated pathohistologically.

The results were as follows:

1. Apposition of bone was seen three to thirty days after tooth extraction in the lower margin of the mandible between the two neighboring teeth inclusive of the extraction wound.

2. Roughing of the mesial wall of alveolar bone and bone resorption of the two neighboring teeth, due to physiologic tooth movement, continued until about 14 days after tooth extraction.

3. The changes resulting from extraction in the periodontal tissues of the two neighboring teeth seven days after extraction were resorption of the distal wall of alveolar 
bone of the second premolar and more remarkable resorption than before of the mesial wall of alveolar bone of the second molar.

4. Apposition of bone was seen 21 days after extraction in the peripheral walls of alveolar bone of the two neighboring teeth. At this point, physiologic tooth movement had already ceased.

5. Between 30-60 days after extraction, many osteoblasts appeared in the mesial side of the second premolar and in the distal wall of alveolar bone of the second molar. Apposition of new bone in strata was observed in some parts. In the opposite side of the alveolar bone, osteoclasts appeared. Periodontal ligaments at the resorpted site were irregular in arrangement and thickness of the bundles. Those at the boneadded site were regular in arrangement and thickness of the bundles.

6. New bone formed in strata 90 days after extraction on the mesial side of the second premolar and in the distal wall of alveolar bone of the second molar. Periodontal ligaments ran straight on the mesial side of the second premolar and in the upper half of the periodontal membrane on the distal side of the second molar. In the lower half of the periodontal membrane, they ran in wavy lines.

7. Displacement of the two neighboring teeth toward the extraction site was remarkable 90 days after extraction. Because of a grater bone addition in the distal wall of alveolar bone of the second molar, tooth displacement was more remarkable in the second molar.

8. Tooth displacement toward the extraction site was sliding of the tooth-body.

9. Changes in periodontal ligaments occurred mainly on the alveolar bone side than in the mid-part of periodontal membrane.

緒言

歯牙および周囲組織疾患により，歯牙が㹂失するてと は日常臨床で多く経験するところである．このような歯

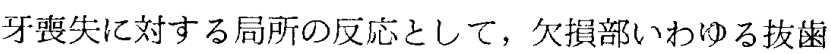
窩の修復過程および機能変化に対応しょうとする残存歯 および周囲変化などがみられる。

なかでも，抜東窩の修復過程に関する研究はちく， Euler $(1923)^{1)}$ が動物で正常抜菌創の治療経過を将理 組織学的に研究して以来, 多くの報留がみられる，その 検索方法も，人や各種動物を使用し，正常，異常拔歯創 の治湶経過について, X線学的, 病理組織学的研究を中 心に, さらに組織化学的, 生化学的研究がなされている. 一方，歯牙欠損による周囲組織の変化汇関しては，曾 槽骨に対する影響について干葉 $(1976)^{2)}$ がラベリング 法, マイクロラジオグラフ法にて詳細に報告している. また, 歯牙尔損後の頜堤の形態変化については, 補緅
学的立場から，村田 $(1965)^{3)}$ ，水谷 $(1974)^{4}$ らかか報告 している.さうに，歯牙欠損のさいの残存歯の位置変化 についても光井ら $(1952)^{5}$ をはじめ, 下総(1955, $1956)^{6,7)}$ ，富士川 $(1958)^{81}$ ，奥野 $(1968)^{91}$ ，石㴖 (1973) ${ }^{10}$ ' らが石育模型による計測やX線による観察な どによって検索している.

このような報告から，歯牙欠損後の㗂堤の形態変化や 残存歯の位置変化か起ることは知られていても, 残存柬 の移動の過程について, 病理組織学的に報告したものは みられない。

そこで著者は，菌牙欠損後の雨隣接残存粷とその周囲 組織の変化を病理組織学的に検絷したので報告する。

\section{実験動物ならびに実験方法}

\section{1. 実験動物}

実験には約 5 才のカニクイザル（Macaca irus）18頭 を使用した。動物は実験前約 1 週間動物飼育舎にて飼育 
し，健康であることを熦認した後に実験に供した。

2. 実験方法

動物はケタラール（塩酸ケタミン）にて静脈麻酔後実 験を行なった。

まず，左右側下顎第 1 大四歯の柬牙植立状態を X線写 真にて観察後, 同部を0.05\%七ビテン液で消毒した後, 左右側下顎第 1 大曰菌周围を塩酸エピレナミン加 $2 \%$ 塩 酸プロカインにより浸潤麻酥し，歯牙周囲勒带を尖刃に て切離後，できるだけ雨槽骨に損傷を与えないように抜 菓を行なった。

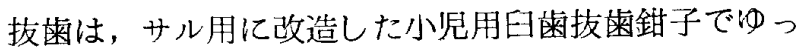
くりと脱臼させ抜去した。 また，拔䨑窩は開放創とし た。

\section{3. 観察方法}

実験後， $3 ， 7 ， 14,21,30,60,90,120$ 日にケ夕 ラール注射液にて莧殺した。

薬殺後，下買骨を採取し，10\%中性ホルマリンにて固 定後，通法にしたがって $5 \%$ 硝酸にて脱灭した。脱灰 後, 下䫈第 2 小曰歯から第 2 大曰藏までの歯牙を含む下 額骨支七ロイシンに包埋後, 近遠心的に15 $\mu$ の連続切片 を作製し，ヘマトキシリン・エオジン染色，アザン・マ ロリ一染色を行い鏡検した。

\section{実 験 成 續}

\section{3 日所見}

\section{I 拔菌窩所見}

抜柬窩の根尖相当部には血餅を認め, その周囲には疎

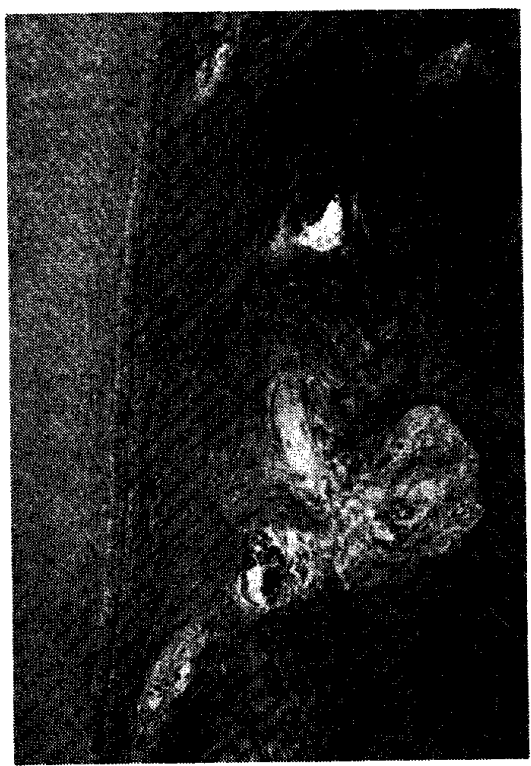

写真 1 拔蒾後 3 日（アザン， ×200） 第 2 小曰雬近心根近心側歯根膜
な線維素網がみられ，その上方には炎症性紐胞が多数出 現している。

抜菌窩壁には歯根膜線維が束をなして残存している が，その走行は不規則である。まう骨壁は鋸蒾状を呈し ているが，破骨細胞の出現はみられない，

根間中淂の骨髄は炎症性紐胞の浸潤が著しく，血管の 充血もみられ，一部の盈細胞は融解消失している。

II 第 2 小臼霜および周囲組織所見

歯剈迶に充血を認める他には，歯牙硬組織に変化はみら れない。また雬根膜の脈管神経隙は抁張し，菌根膜線維 間には線維芽細胞の数の增加がみられる(写真 1 )。

1. 遠心根周䀞組織

a . 遠心側

茵頸部では蒾根膜線維は断裂し，線維束間は踈で，炎 症性細胞の浸潤が著しい。また宷根膜線維は小波状に走 行している，乙の走行は䨑槽骨側で著しく，セメント質 側ではほぼ正常に走行している，歯槽骨骨壁は平坦で， 著変はみられない。

\section{b . 近心側}

雬根膜線維は雪槽骨側で小波状を，七メント質側では ゆるやかな波状を呈している。

雪槽骨骨壁は鋸茵状を呈し，骨吸収が著しく，破骨胞 細も各所にみられる(与真 2 )。

\section{2. 近心根周囲組織}

\section{a . 遠心側}

菌根膜線維に著変はみられない。

歯槽骨骨壁は平坦で，著変はみられない。

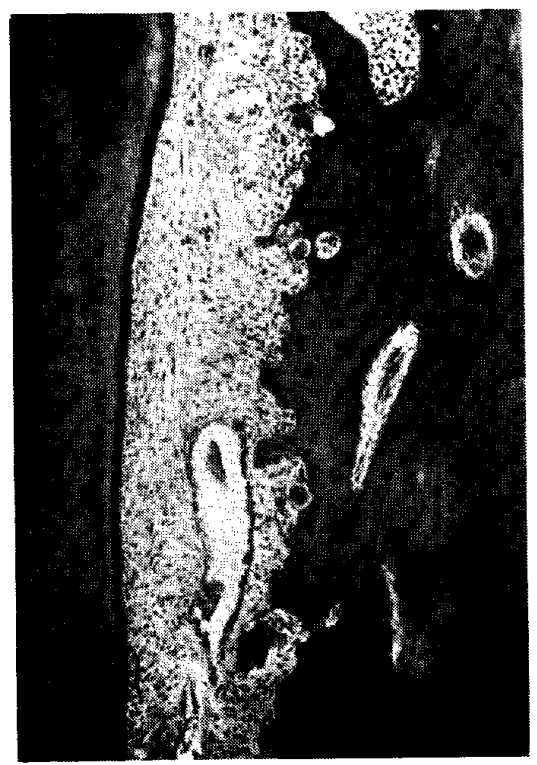

写真 2 拔菌後 3 日 $(\mathrm{H} \cdot \mathrm{E}, \times 100)$

第 2 小曰蔝遠心根近心側雪槽骨 
b . 近心側

歯頸部の荬根膜線維は小波状に走行している。雨根膜 下半部の線維は畨槽骨側で小波状に走行し，七メント質 側ではりるやかな波状走行を呈している。

菌槽骨骨壁は鋸菌状を虽しているが，破等細胞はみら れない。

III 第 2 大曰雬および周囲組織所見

雨牙および菌根膜の脈管神経陌の所兒は第 2 小曰柬所 見と同じである。

1. 近心根周囲組織

$$
\text { a . 近心側 }
$$

歯頸部の歯根膜線維は抜歯窩側に向って版射状に走行 し, 線維束間は踈となっている。また線維閶に炎症性細 胞の浸潤が著しい。

粜槽骨側の柬根膜線維は小波状の走行を是し，一部の 線維束は細く，その走行が不規則である。セメント質側 の線維は規則的に配列, 走行している (写真 3 ).

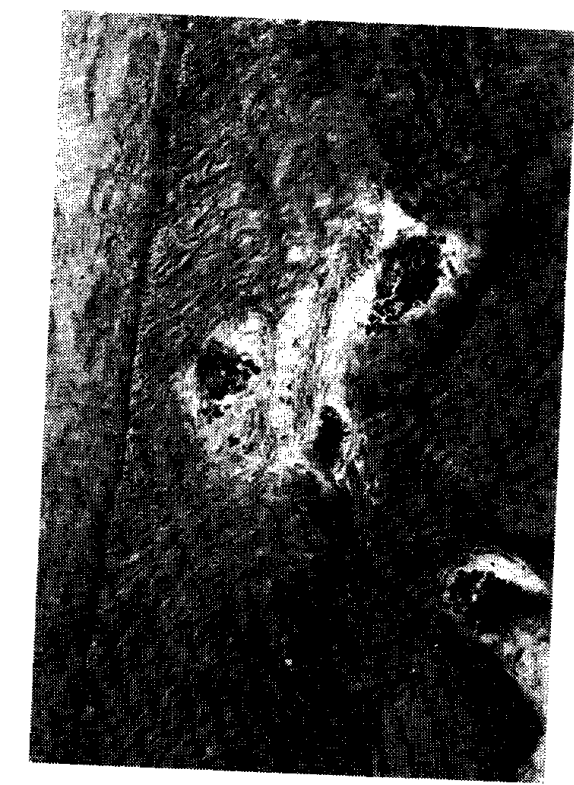

写真 3 抜菌後 3 日（アザン， $\times 200$ )

第 2 大臼菌近心根近心側歯根膜

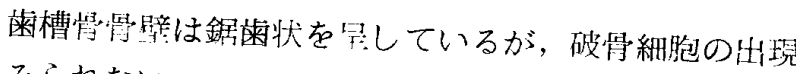
はみられない。

b . 遠心側

蒾根膜線維に変化はみられず，雨槽骨骨壁も平坦で著 変はみられない

2. 逯心根周囲組織

$$
\text { a . 近心側 }
$$
る.

歯根膜線維は霜槽骨側ておいて波状の走行を呈してい
蒾槽骨骨壁はやや鋸函状を呈しているが，著変はみら れない。

$$
\text { b . 遠心側 }
$$

歯根膜.上半部の線維は全体的に小波状の走行を呈して いる。

㐘槽骨臂壁には変化はみられない。

\section{7 日所㫕}

\section{I 拔歯窩所見}

坡歯窝の表層部には血餅および線維素網が残存し，一下 方は新生血管を伴う肉芽組織の形成が著明で，根尖部は 梁状の類骨組織の形成がみられる，抜柬營壁の上半部は 破骨紐胞が多数みられ，骨吸収がさかんで，同部にみら れた霜根膜線維は変性, 消失している.下半部では造省 細胞が多数配列している.

抜歯筒周囲および根間中隔の上半部の惄髄腔は炎症性 細胞の浸潤が著しく, 血管は允血, 抆張していて, 骨吸 収がさかんである。また下半部では，炎症性細胞の浸潤 は少なく，骨縁には造骨細胞が多数みられ，一部では類 骨細胞の形成がみられる。

抜雪窩下方の骨髄は骨髄細胞で満されているが，血管 は充血, 拡張し, 一部の骨縁には梁状または層状の新生 骨組織の形成がみられる(写真 4 )。また顎骨下縁部に は梁状の新生骨の形成がみられる(马真 5 )。

II 第 2 小曰歯および周囲組織所見

歯髄の充血は 3 日所見よりさらに著しく, 筧部歯髄で

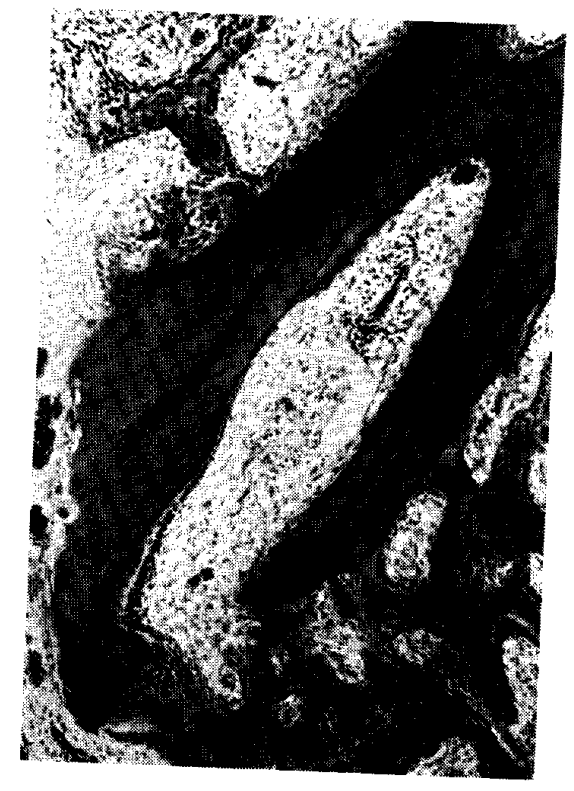

写真 4 抜歯後 7 日 $(\mathrm{H} \cdot \mathrm{E}, \times 200)$ 拔菌裔周囲雨槽骨内部の管新生 左上方は抜简底部の骨新生 


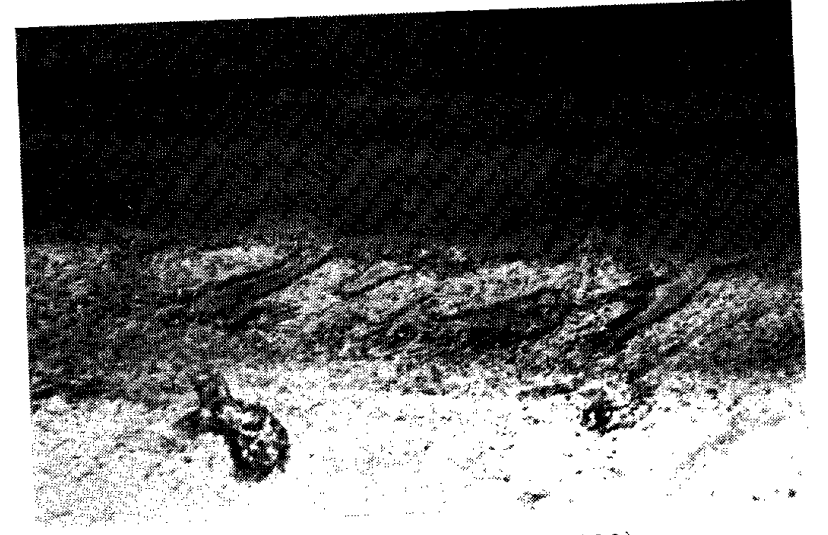

写真 5 抜䨑後 7 日 $(\mathrm{H} \cdot \mathrm{E}, \times 100$ 拔歯䆚に相当する下䫛骨下縁

は一部に出血宩がみられる。蒾根膜の血管は 3 日所胃よ りさらに充血が著しく，特に技瞇側に隣接する歯根膜に 著しい，歯根膜の線維芽細胞はさらに数の增加がみられ る.

\section{1. 遠心根周团組織}

a . 遠心側

柬頸部では炎症性細胞の浸㵎がさらに著しく，炎症は 蒾根膜腔へと波及している。

匊根膜線維は全体的に数の減少がみられる。特に歯槽 当側では各所に骨吸収がみられるため，霜槽骨に進入す る線維束は少なく，線維束間は踈となっている。また破 骨細胞のみられる部分では畨根膜線維は骴に進入するこ となく，走行も不規則になっている。セメント質側の菓 根膜線維はほほ規則的に配列している（写真 6 )。

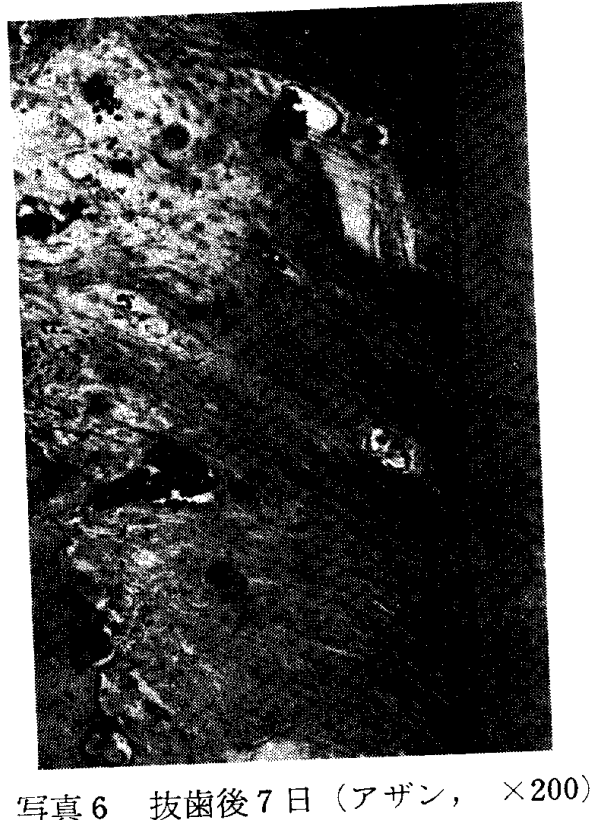

第 2 小曰蒾遠心根遠心側蒾根膜
䨑槽骨骨壁は上半部で破兴現象が著しく，隣接する骨 髄腙は炎疗細胞の浸潤が著しく，骨吸収がみられる。

b . 近心側

歯根膜線維:束は全体的に絒く，脈管神経隚付近では線 維束間が柾である。セメント質側の歯根膜線維東は遠心

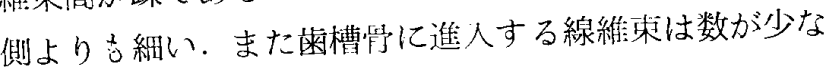
く，走行も不規則となっている。

蒾槽骨骨壁は鋸歯状を呈し，上半部では破骨細胞が多 数みられる。

III 第 2 大曰歯および周囲組織所見

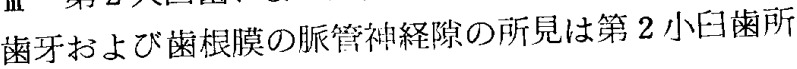
見と同じである。

\section{1. 近心根周囲組織}

a. 近心側

雬頸部は炎症性細胞の浸潤がさらに著しく，炎症は歯 根膜腔へと波及している。

歯根膜上半部の線維は歯槽受の破骨現象のため数の減 少がみられ，線維束間は柾で，骨に侵入する線維束はわ ずかしかみられない，歯根膜下半部の線維はセメント質 側では規則的に配列しているが，蔝槽骨側では強い波状 の走行を呈している(写真 7).

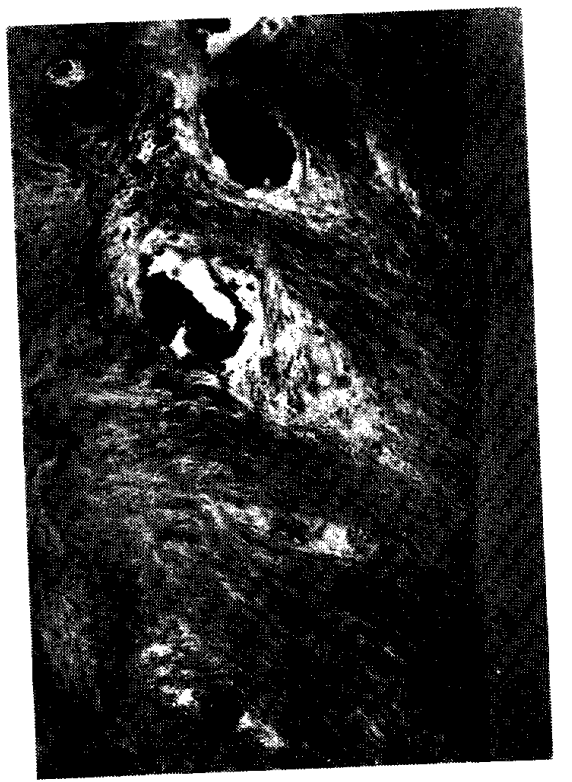

学真 7 抜歯後 7 日 アアザン, $\times 200$

第 2 大些歯近心根近心側荬根膜

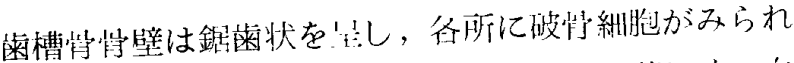

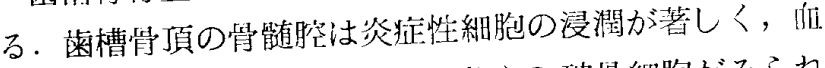
管は允血，桩張し，狊緣には多くの站骨細胞がみられ る。しかし，下半部の骨髄腔では炎症性細胞は減少し， 破悬細胞も少なくなり，造骨細胞が多数配列し，一部で は類骨組織の形成がみられる。 
b . 壹心側

蒾根膜線維束はやや細く，七メント質側で線維の走行 が急傾斜しているのみで，その他著変をみない。

歯槽骨骨壁は平坦で著変はみられない。

2. 遠心根周四組織

a . 近心側

雬根膜線維に変化はみられない。

来槽骨骨壁は鋁䨑状を呈しているが，破骨紐胞はみら れない，隣接する骨髄腔にも著変はみられない。

b - 遠心側

霜根膜線維に変化はみられない。

㐘槽骨骨壁にも変化はみられない。

\section{4日所見}

I 枝歯窩所兒

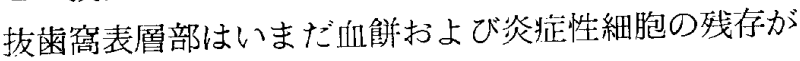
みられる，その下方は闪芽組織で満され，多くの新生而 管の形成がみられる。また根矢部より形成されている新 生帩はさらに增し，学梁の巾も広くなっている。

拔雨窝上方部の歯槽具は吸収がみられ，骨髄腔には炎 症性紐胞の浸潤が著しく，破管細胞が多数みられる。

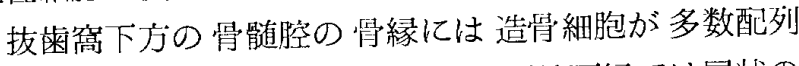
し，各所に梁状の新生䟫がみられ，顎骨下縁では層状の 新生莦が巾を堄している。

\section{II 第 2 小曰棶および周国組織所見}

歯䯚道は 7 日所見と変化はみられない。歯根膜の血管の

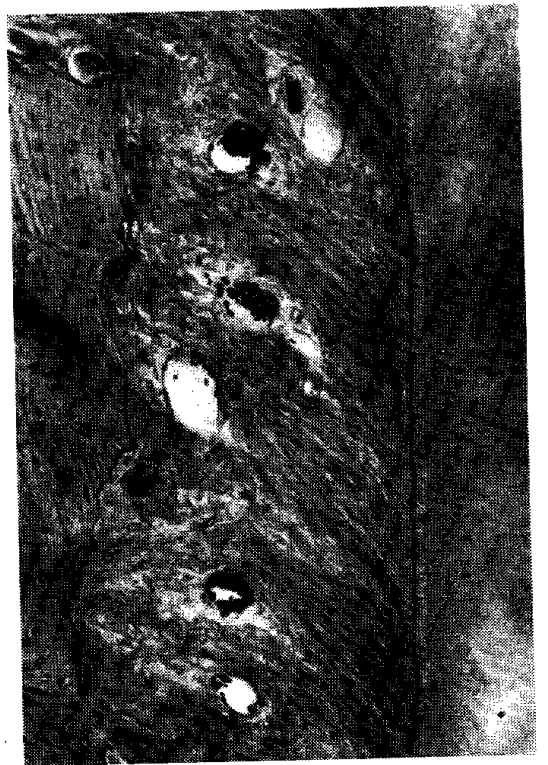

写真 8 抜蒾後 14 日(アザン， ×200) 第 2 小曰歯遠心根遠心側歯根膜
批張は 7 日所㫕ほど著しくない。

1. 遠心根周囲組織

a . 遠心側

㐘頸部にみられた炎症性細胞は雪根膜下方へとさらに 浸潤している．䨑根膜上半部の線維はほとんど融解消失 している。蒾根膜上半部より中部に至る米根膜線維束は 細く柾で，その走行もまったく不規則である．歯根膜中 部より下半部に至る線維束はセメント質側ではやや細く 密に配列しているが，歯槽骨側では骨に進入する線維東 は太いが弱々しく，配列が踈である．またその走行は強 い波状を呈している(写真 8 )。

歯槽学上方部の骨壁は破骨が著しく，隣接する骨髄膑 は炎症性紐胞で満され，骨縁には破骨細胞が多数みられ る。また歯槽骨下方部の骨壁には造骨細胞の配列がみら れる。

b . 近心側

宩根膜腔は狭くなり，雬根膜線維は王平され，線維の 走行は不明瞭である.

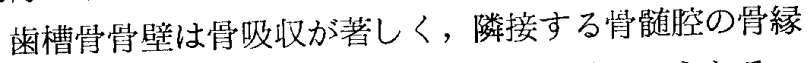
は造骨細胞が多数配列し，層板状の新生骨がみられる。

2. 近心根周囲組織

a . 遠心側

雬根膜下半部の霜槽骨側で雬根膜線維束が太く，波状 の走行をしている，雪槽骨に進入する線維束は造骨細胞 の間を通り，その間隔も疎となっている.

米槽骨はその下半部で骨壁に造骨細胞の出現がみられ るが，骨新生はみられない。

b · 近心側

歯根膜上半部の線維束は密で，その走行も直線的であ る。柬根膜下半部の線維束は 7 E所見と著変はみられな い.

歯槽骨骨壁も 7 日所見に類似していて，隣接する骨葡 の血管は充血，拡張し，骨縁には骨の新生と吸収が交互 にみられる。

III 第 2 大田曾および周团組織

歯奮は第 2 小曰歯の所見と同様である．近心根近心側 の根下半部, 抢よび根分岥部では第 2 セメント質の形成 がみられる。

1. 近心根周囲組織

a. 近心側

歯頸部の炎症性細胞は減少しているが，線維は融解消 失している.

歯根膜線維は 7 日所見に比べ数の壃加がみられるが線 維束はやや細い，㐘根膜中部より下半部に至る線維束は 
歯根膜中央部より曾槽骨側に近い部分で㺈い波状がみら れる、またセメント芽細胞および造骨細胞の配列のみら れる部分では他にくらべ線維束がやや太くなっている が，各束の太さは不整である。

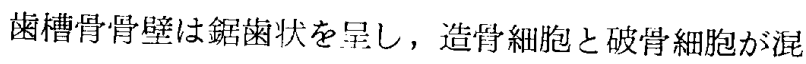
在している，また隣接する骨邻道腔には炎症性細胞の残存 がみられるが，骨䋑には類骨組織が多量にみられる。

b . 遠心側

雨根膜腔は近心側にくらべ狭くなっている，柬根膜線 維束は 7 日所見にくらべ太く密となっている。また線維 の走行は不規則である(写真 9 ).

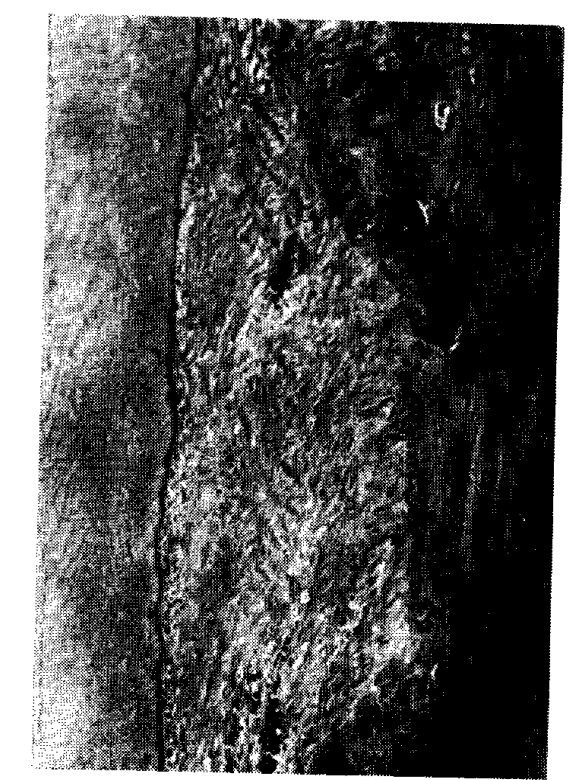

写真 9 抜雪後14日(アザン, ×200)

第 2 大巨歯近心根遠心側菌根膜

歯槽骨骨壁は鋸菡状を䛼し，破骨細胞が一部にみられ る。

2. 遠心根周国組織

a . 近心側

雨根膜線維は7 日所罗にくらべ,走行がややゆるやかな $\mathrm{S}$ 子状を呈するようになる以外には著変はみられない。

䨑槽学量壁には造骨紐胞の配列がみられるようにな る、また隣接する骨髄腔には類骨組織の形成が著しく， 層板状の新生鱼むみられる。

\section{b . 遠心側}

歯根膜下半部の雪根膜腔が狄くなっている，歯根膜維 線は 7 日所見にくらべ，やや数の増加がみられる．蕃根 膜腔の狭くなった部分では線維の傾斜が強くなってい る。

歯槽骨骨壁は銬歯状を呈するようになり，下半部では

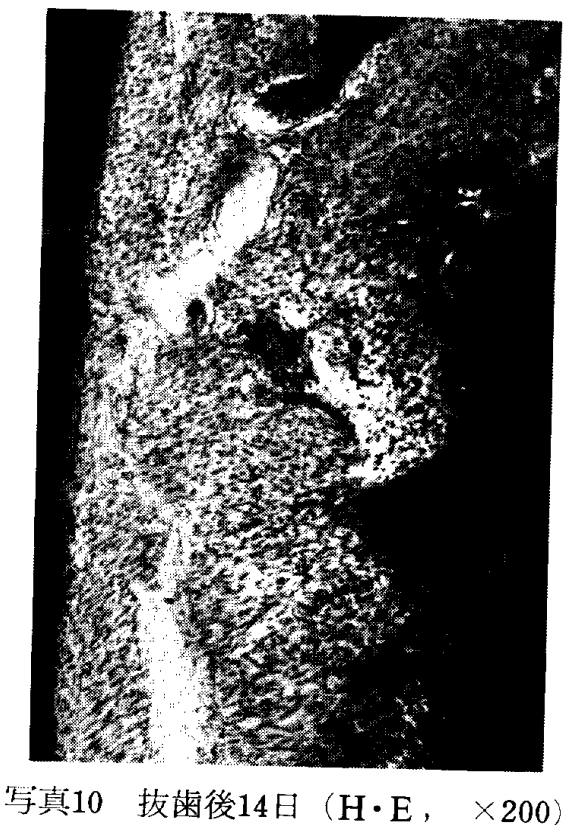

第 2 大巨歯遠心根遠心側蒾槽省

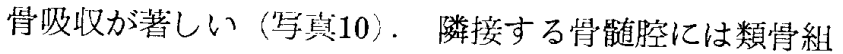
織がみられ，層板状あるいは梁状の新生学が一部にみら れる。

\section{1 日所兒}

I 拔柬简所罗

扳歯窩の最表層は近遠心側より伸展してきた上支組織 により被われる，上文值下は肉芽組織で满され，抜菌简 は剧囲骨壁より形成された新生劣が上方に问って梁状に 伸展し，その巾も堌している。

問同の骨髄腔は一部炎症性細胞の残存もみられるが， 闪牙組織により満され，肖縁には造霄細胞が多数配列 し，梁状の新生骨がみられる。

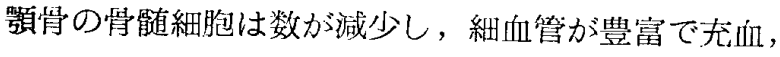
昖張している．新生骨は14日所見にくらべて币を増して おり，周囲には線維枒紐胞がみられる。顎骨下縁は14日 所罗と変化はなく，新生骨は層板状に形成されている。

II 第 2 小曰䡒㧍よび周囲組織所見

䔥髄内の血管の允血は消退しているが, 出血巣は残存 している、第 2 セメント質の形成は14日所見よりウを増 している. 雨根膜の脈管神経腺はやや㹟くなっている が，大きさは不同である。

1. 遠心根周囲組織

a. 遠心側

迷根膜線維は全体的にその束が太くなり, 配列も密之 なっている。しかし，兩頸部の線維束は走行および配列 が不規則である．他の部分の線維束の走行は波状を呈し 


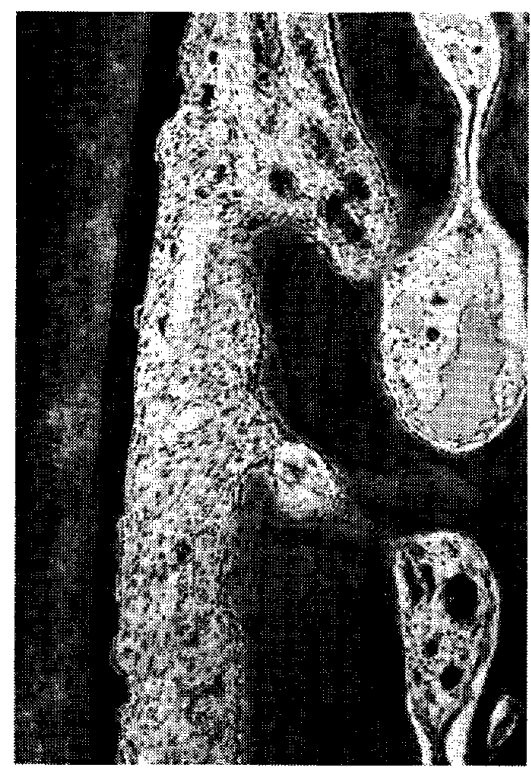

马真11 抜歯後21日 $(\mathrm{H} \cdot \mathrm{E}, \times 100)$

第 2 小巨歯遠心根遠心側歯槽骨

ているが，14日所見ほど著しくない，歯槽骨骨壁は平坦 となり，特汇上半部ではわずかであるが一層の新生骨が 形成されている。また蒾槽頂では上没側に向う類䒿組織 がみられる，隣接する骨髄腔は層状あるいは梁状の新生 骨がみられ，骨縁には造学細胞が多数みられる（㝍真 11).

\section{b . 近心側}

雬根膜腔は14日所見にくら心広くなり，還心側と同じ 巾をしている。

歯根膜線維は全体的に数の減少がみられる。歯槽骨の

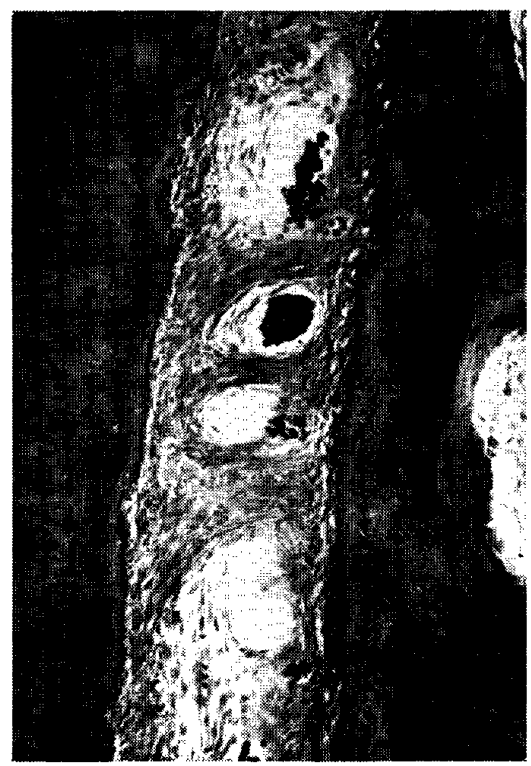

写真12 抜菌後21日(アザン，×200) 第 2 小囦歯遠心根近心側畨根膜
骨新生が著しいため，粜槽骨に進入する線維束の数が著 しく娍少している。しかし，線維束は太くなっている (写真12). 菊根膜線維は波状を呈し，下方に行くにした がって攸斜が強くなっている.

柬槽骨骨壁は平坦となり，歯槽骨上半部では層板状に 形成された新生骨の巾が広くなっている。下半部ではや や凹凸を呈しているが，わずかに新生骨がみられる。

\section{2. 近心根周国組織}

\section{a . 遠心側}

歯根膜線維束は太く，密に配列して，その走行は波状 を旺している。

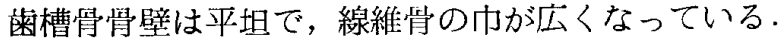
隣接する筒髄腔の血管は允血，抾張しているが，造骨綝 胞の数は少ない，柬槽骨下方の骨䯣腔には梁状の新生骨 がみられる。

\section{b. 近心側}

霜根膜線維は 14 日所見にくらべ数の堌加がみられ，線 維束の走行は雬根膜下方へ问うにしたがって波状が著し くなっている(写真13).

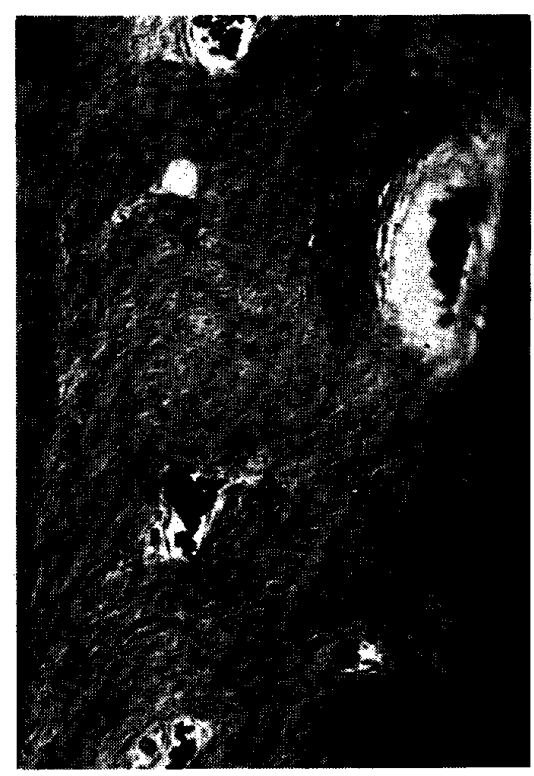

写真13 抜菌後21日（アザン， × 200）

第 2 小曰歯近心根近心側蔽根膜

籴槽学骨壁は鋸歯状を星しているが，上半部では新生 骨の形成がみられ，平坦化がみられるが，下半部では特 に変化はみられない，隣接する骨䯣腔は14日所見と変化 はない。

III 第 2 大田歯および周囲組織所見

㐘髄の所見は第 2 小囦菌と同様である.第 2 セメント 質の形成は近心根下半部汃遠心根全周にみられる。歯 
根膜の 脈管神経隙は第 2 小曰荗と同に゙所見を 呈してい る.

\section{1. 近心根周囲組織}

a . 近心側

菌根膜線維は 14 日所見にくらべ線維束がやや太くな り，走行が規則的になっている。

歯槽骨骨壁は平坦となり下半部では線維骨の巾が增し ている、裻髄腔の一部ではいまだ炎症性細胞がわずかに 残存しているが，骨緣には一屏の造骨細胞が配列してい る.

\section{b ．遠心側}

歯根膜腔は14日所見にくらべ広くなっている．線維の 太さ, 配列には変化はみられないが，その走行が小波状 を星するようになり（写真14），第 2 セメント質形成部 に進入する線維束が践となっている。

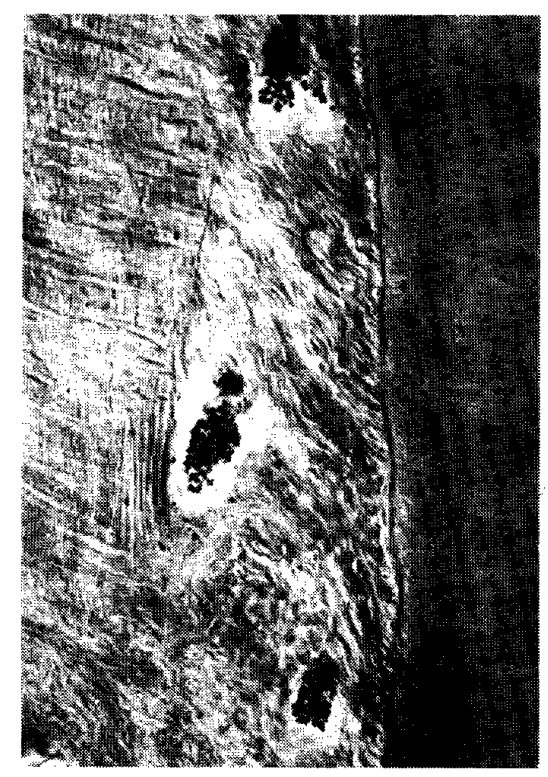

写真14 抜䨑後21日（アザン， $\times 200)$

管 2 大曰歯近心根遠心側雬根膜

歯慒骨骨壁は平坦となり，雬槽骨上半部では線維诗の ウが広くなっている。

2. 遠心根風团組織

a . 近心側

歯根膜線維は14日所見にくらべ著変はみられないが， 歯槽骨下半部に進人する 線維束の間隔が踈となってい る。

歯槽狺骨壁は14日所見と変化はみられないが，線維省 のウがやや增している。

\section{b . 遠心側}

歯根膜腔の巾は他部と変化はなくなっている，歯根膜
線維は小波状走行が著明であるが，他は14日所見と変化 はみられない。

歯槽骨骨壁は下半部でやや凹凸不整を呈しているが， 骨縁には一層の新生骨がみられる，隣接する骨䯣腔には 変化はみられない。

30 日所見

I 抜菌䆝所見

雪肉上皮はその巾を増し，二次乳頭の形成が著明であ る.上皮下の結合組織は近遠心的に横走している，抜蒾 筒は新生能で満され，骨梁は21日所兌よりウを增してい

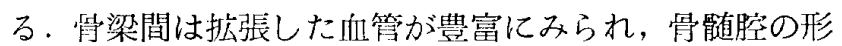
成がみられる。

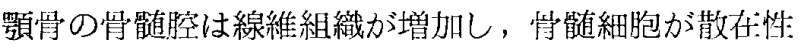
に認められる。また骨梁は新生骨の形成のため巾が堌し ている、㖽冒の下縁部はほぼ平坦になっている。

II 第 2 小囦蔽および周囲組織所見

歯䯣内の血管の无们はほぼ改善されている。第 2 七メ ント質の著明な形成を根尖部付近で惢める。歯根膜の脈 管神経陌はさらに秋くなっている。

1. 遠心根周国組織

a . 臺心側

蒾頚部の線維束は太くなり，上没側，拔歯側，雬槽頂 側一と長人直線的徒行している。

歯根膜上半部の歯根膜線維はゆるやかな波状を呈し， 規則的に配列しているが，歯槽岁側では破骨のため一部 線維の走行の不規則な部分もみられる(写真15)。また

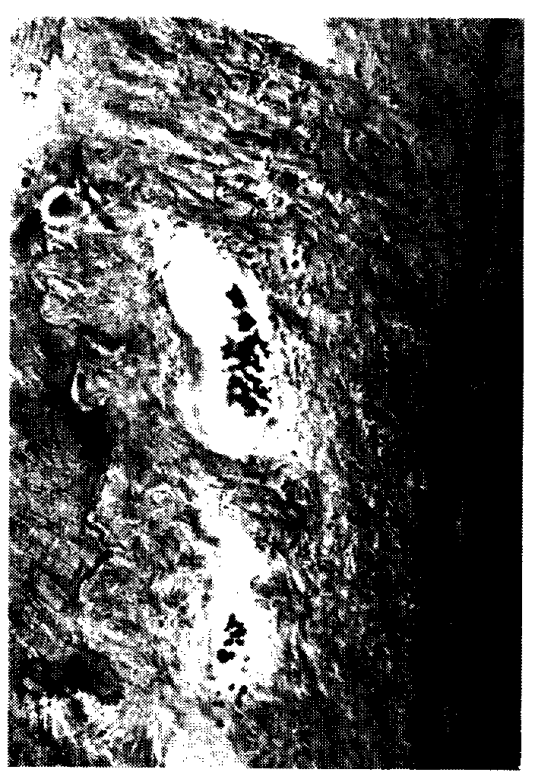

写真15 抜菌後30日（アザン， ×200） 第 2 小曰米遠心根遠心側歯根膜 
柬根膜下半部の線維は独い波状を寻している.

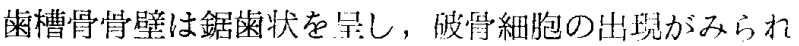

る。隣接する筲髄腔は21日所兒之著変はみられない。

b . 近心側

桻根膜線維は21日所兒と変化はない。

歯槽骨骨壁の 新生骨の门は21日所罗よりさらに䏴加 し，惄縁には造骨細胞が多数配列している。隣接する少 骮腔は芚血した向学や肉芽組織がみられる。

\section{2. 近心根周井組織}

a . 遥心側

雪根膜線維はその走行が21月所㫕にくらー゙真線的にな る以外には変化はみられない。

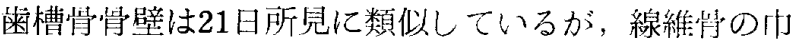
はそれほど広くない。

\section{b . 近心側}

歯根膜線維は21月所見と変化はみられない。

米槽䟫䟫壁は平坦となる以外に変化はみられない。

III 第 2 大曰歯および周囲組織

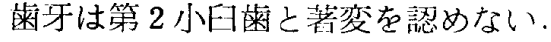

1. 近心根周囲組織

a. 近心側

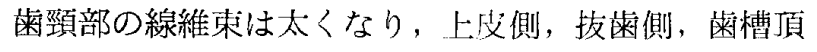
側へと長く直線的に走行している（㝍真16。

菊根膜線維は21日所見と同㫽である。

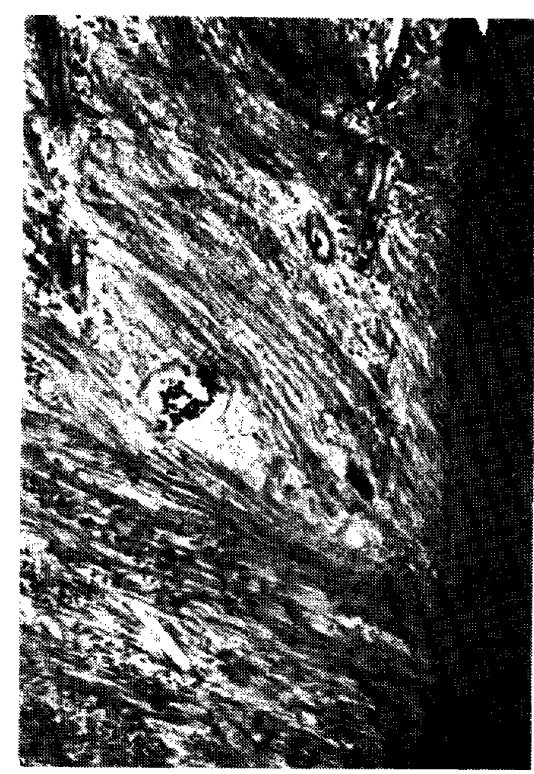

写真16 抜雨後30日(アザン， $\times 200$ 第 2 大的歯近心根近心側歯根膜

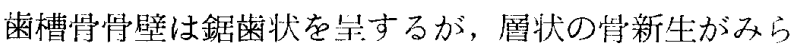
れ，その辺縁には多数の造莦細胞がみられる（写真 17 。

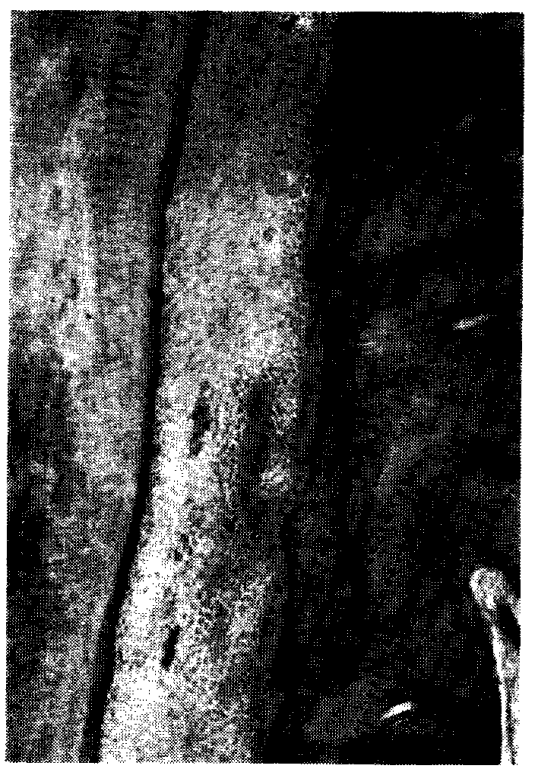

学真17 拔歯後 30 日 $(\mathrm{H} \cdot \mathrm{E}, \times 100$

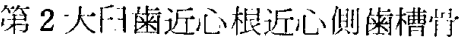

また隣接する背髄腔は新牛等形成のため狄くなってい 万.

b . 遠心側

歯根膜線維は全体的に太く，配列が密である。線維の 走行は雪槽骨側では波状が著しく, 粜根膜下方に至るに したがって，全体的に小波状となる。

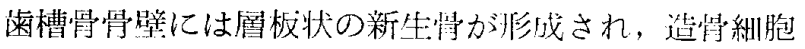
も多数配列している。

2. 遠心根周国綃織

a . 近心側

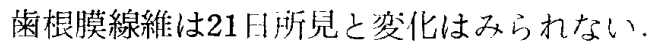

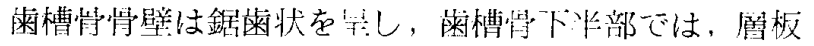
状の新生南の非成がみられ，やや平坦となっている 言

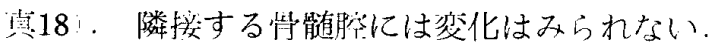

b . 遠心側

米樹膜線維束はやや凡くなるが，その走行，配列は21 H所見と変化はみられない，また䨑槽省に進入する線維: 束は特に太くなっている。

料槽骨骨壁も21日所圥と者変はみられない。

\section{7所見}

\section{I 拔歯䆚所見}

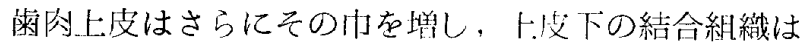
而绦在幽間を横起ている。

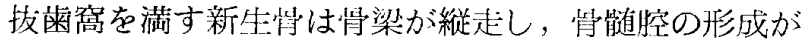
さかんである。 


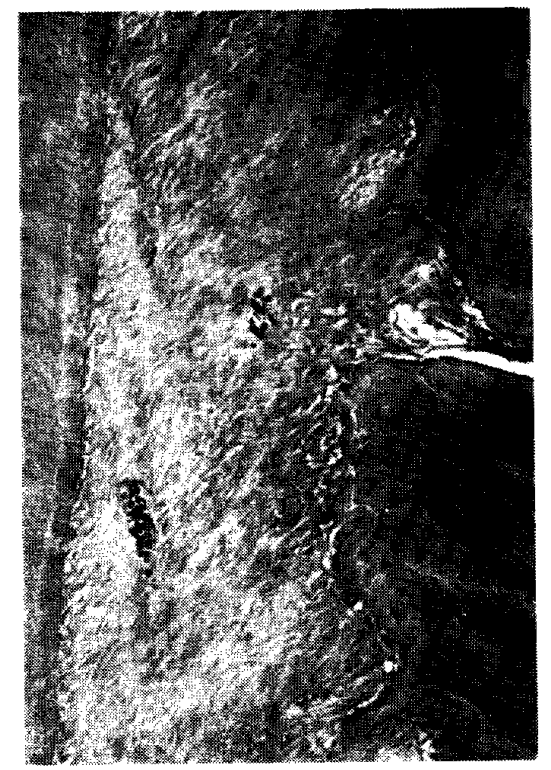

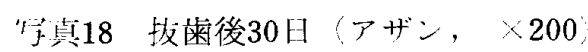

第 2 大巨歯遠心根近心側粜槽恃

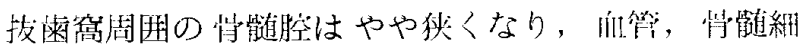

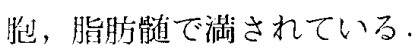

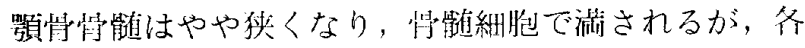
所纪空胞もみらる。

II 第 2 小E寸歯およよ゙周团組織所兒

近心根および遠心根の各近心側の根下半部ではセメン

卜筫に波状收仪がみられる。

1. 邉心根周井組織所兒

a . 檯心僛

歯根膜腔はやや狄く，歯根膜線維は全体的に密に配列 している.画根膜線維の走行は30日所見と類似している. 䨑槽学䟫壁は下方部をのぞき平坦で何ら著変はみられ ない，下方ではやや山らら不整であるが，破筒細胞はみら

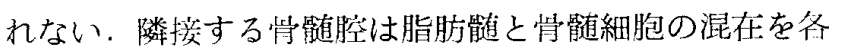
诿に認める。

\section{b. 近心側}

雪根膜線維は30H所見にくらべ密に配列している。線 維束の走行は活等線的であ万が，下方に古うにしたが って波状を高する。また根下记部セメント質および橉槽 崩に焦人する線維束は太くなっている（与真19;。

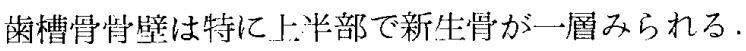

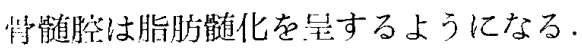

\section{2. 近心根雕国組織}

a . 遠心側

宷根膜線維束は30日所見にくらべ太くなっている。そ の走行は波状を旺し，強く傾斜している 守真20)。

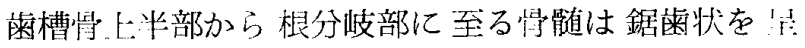

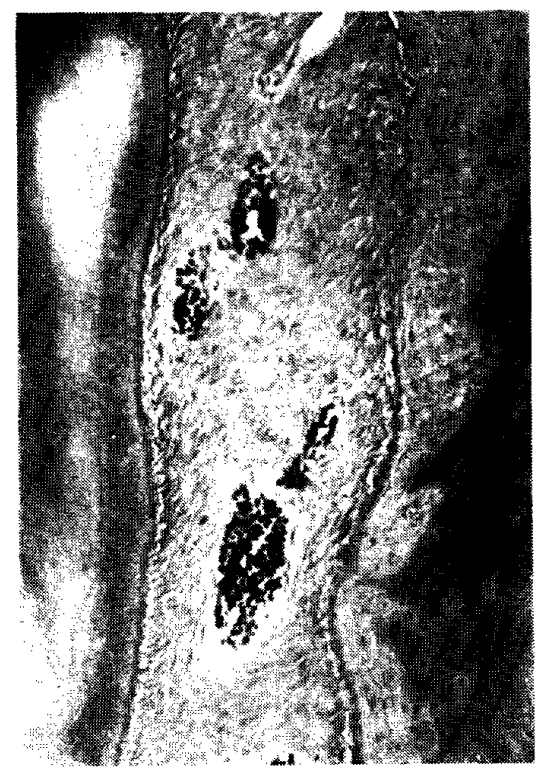

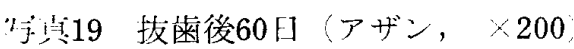

第 2 小曰霜遠心根近心側菌根点

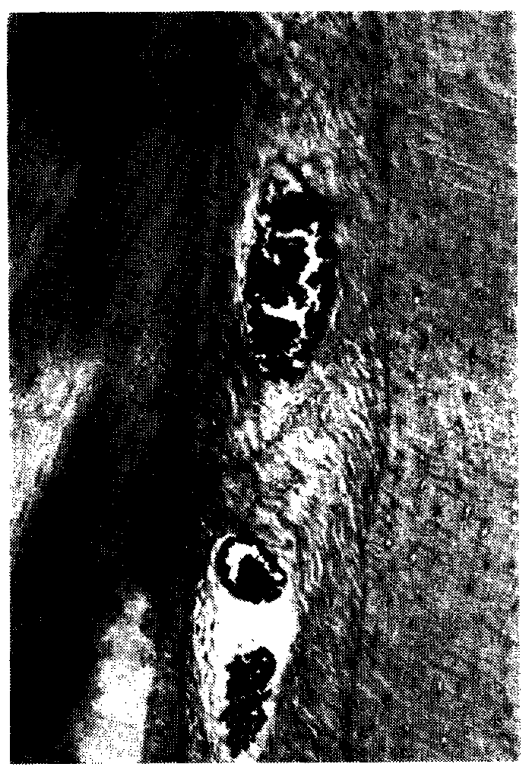

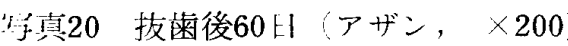

第 2 小四㐘近心根遠心側歯根膜

し，破筒紏胞もわずかにみられる。また下判部では骨壁 は平暏で，造岌細胞の配列がみられる。

b . 近心側

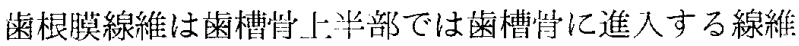
束は太くなっているが，配列，走行に変化はみられな い。だト半部の線維は雨槽骨側で配列が不規則になっ ている。

蒾槽岌は上半部で新生消の形成がみられ，造骨細胞も 豊富にみられる。しかし，畨槽情下半部では骨壁は鋸菊 状を呈し，破骨紐胞も一部にみられる。 
III 第 2 大妇歯および周囲組織所見

遠心根遠心側根尖部はセメント買の波状吸収がみられ るが，破雨細胞はみられない。

\section{1. 近心根周囲組織所㫕}

a . 近心側

歯根膜腔はやや狄く，因根膜線雜の数は30日所見と变 化はないが，波状を呈し強く顶斜して走行している 真21) 。夹恨膜下半部のセメント質に進人する線維束は 太く，配列が踈である。

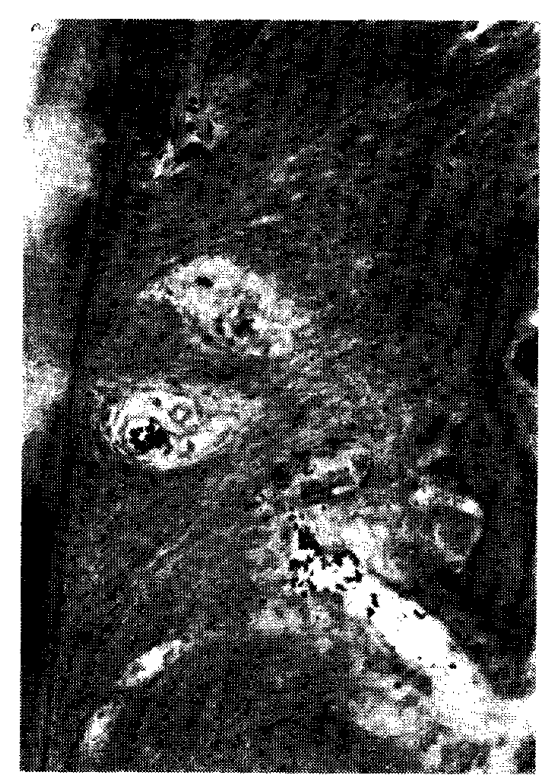

字索21 披歯後60日(アザン, ×200.

第 2 大间歯近心根近心側菌根膜

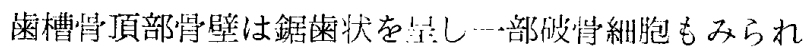
るが，他部はほぼ平㫜となっている，薮接する骬䯙腔は 脂肪髄化が著しい。

\section{b . 遠心側}

菌根膜腔は近心側にくらべ㕕い，植根膜線維は30日所 見にくらべ全体的にゆるやかな波状を區し，莱根膜中央 部では一部強い波状がみられる。

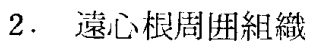

\section{a. 近心倒}

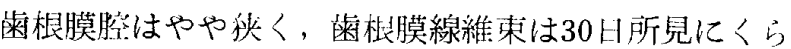
べ太く密に配列している。また線維は強く傾䣄し，波状 を热している。

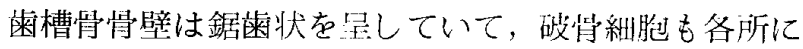
みられる。

$$
\text { b. 阌心㒋 }
$$

歯根膜腔は近心側より広い。歯根膜線䌖束は30日所罗

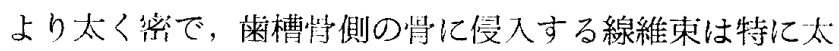

く，配列が柾となっている，写南22。

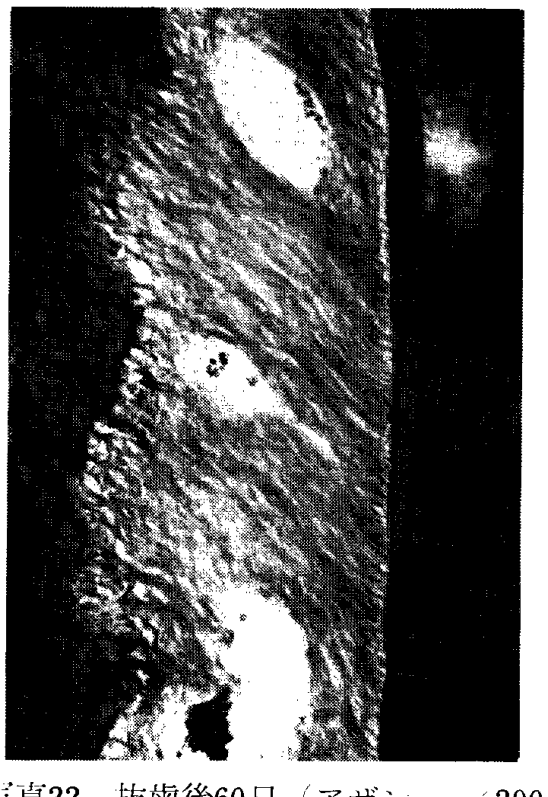

当真22 报歯後60日(アザン， $\times 200$

第 2 人F

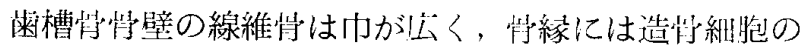

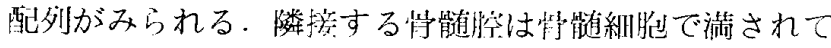
いる。

\section{0 日所完}

I 拔歯窩所兒

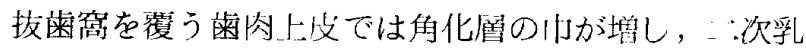
站の形成も著明である。上芚下は疎性結合織が横起して いる、技歯窩は骨の改造がみられ，岌の巾も広く，留髄

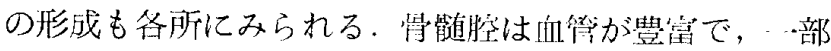
では脂肪髄もみられる。

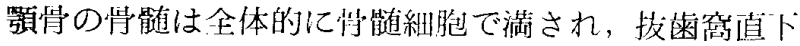
の出軻腔には脂肪骵もみられる。

\section{II 第 2 小罒雬および成用組織听罗}

歯牙は根尖部周囲の第 2 セメント質が近心側根尖部で 后くなっている以外には著変はみられない。

1. 遠心根周囲組織所見

$$
\text { a. 遠心側 }
$$

畨根膜腔は60日所西よりさらに狱くなっている。菌根 膜線維はその数に変化はみられないが，全体的に走行が

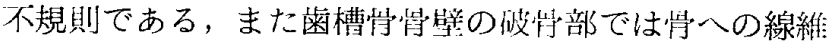
の進入はみられない。

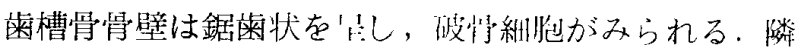

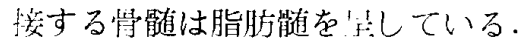

$$
\text { b . 近心側 }
$$

柬根膜線維は60日所見と変化はみられないが，歯槽掉 
に侵入する線維束の附列が䠅となっている。

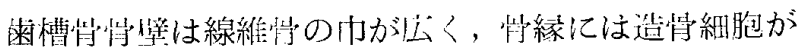

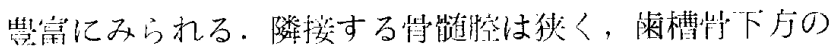

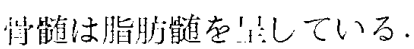

\section{2. 近心根周囲組織所是}

\section{a . 臺心側}

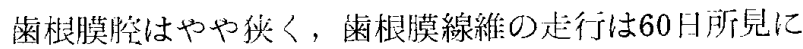

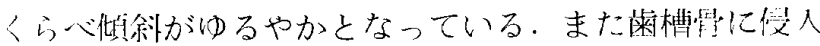
する線維は佊肾部ではみられなくなる。

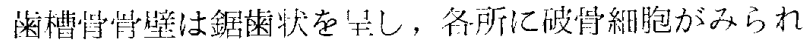

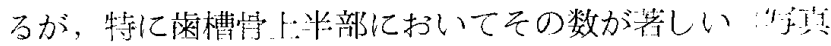
23 .

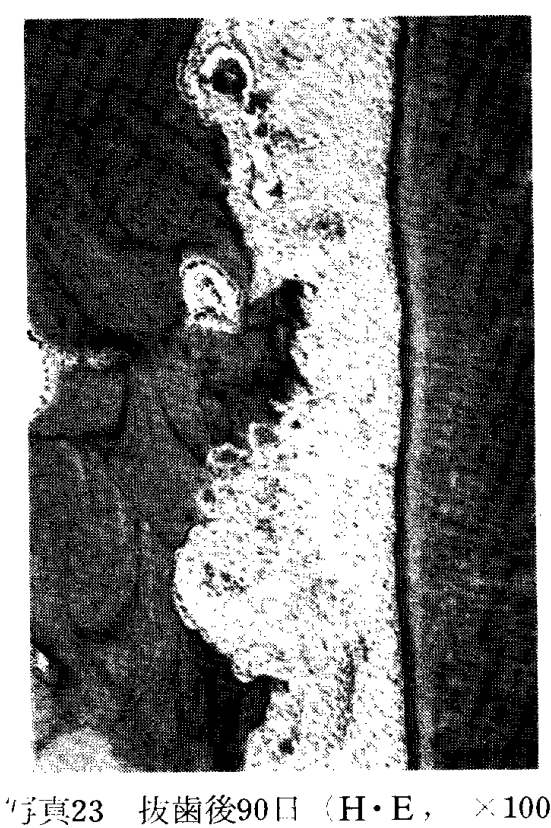

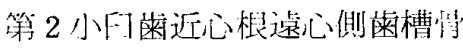

b . 近心側

蒌杜膜線維の数に变化はみられないが，䨑根膜上半部 では線維の起行が直線的である(け其24）。また下半部

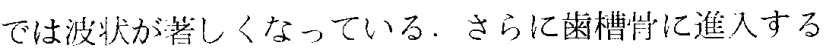
線維間が徚と店っている。

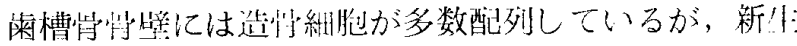
少の形成は著しくない。

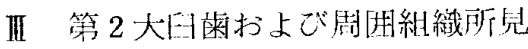

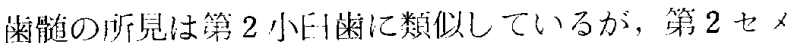
ント質の形成は近㟫心恨根处部から迢心側においてその ウが著しく広い。

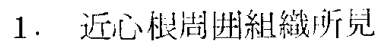
a. 近心側

霜根膜腔は狄く，蒾根膜線維はやや数の減少がみられ

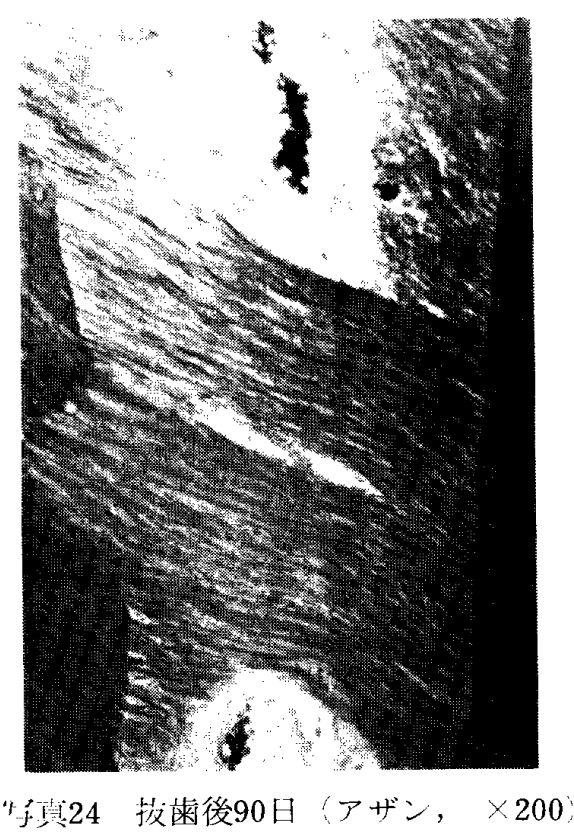

第 2 小F1柬近心根近心側蒌根膜

る。またセメント質側の線維はほぼ規則的で直線的であ るが，雪槽屿側では波状が著しい，また破省細胞の出現 解では線維の走行が不明暸である

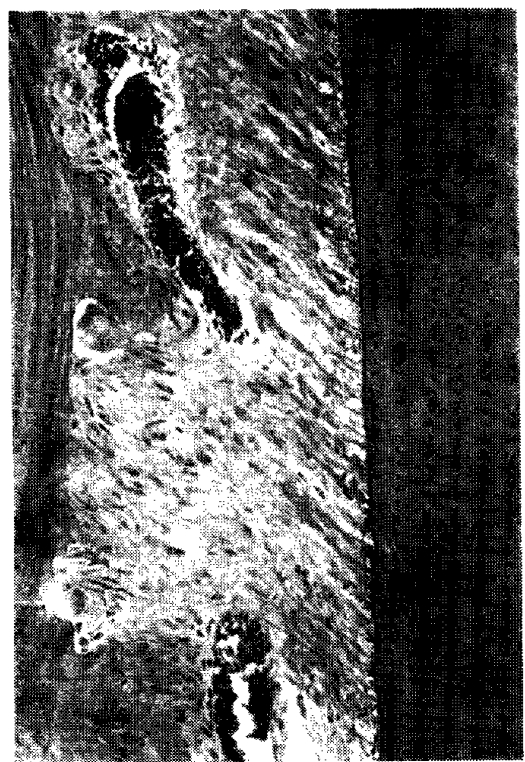

‘j.真25 抜崡後90月(アザン， × 200) 第 2 大巨歯近心粮近心側菌根膜

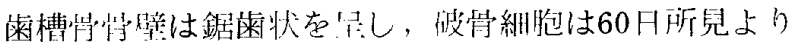
数の增扣がみられる。

\section{b . 遠心僛}

㐘根膜腔は近心側にくらべて広く，線維の洼行はゆる やかな $\mathrm{S}$ 等状を珰している。

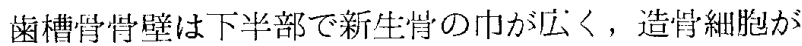

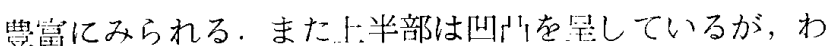


ずかに兴新生がみにれる。

2. 遠心根周团組織所罗

a . 近心側

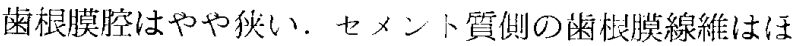

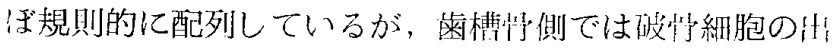
現部で線維は不規則で姃となっている。

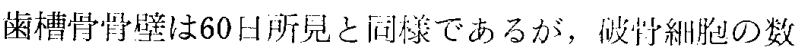

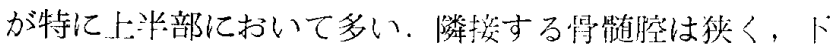

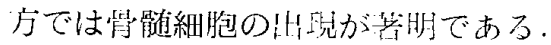

\section{b . 遠心側}

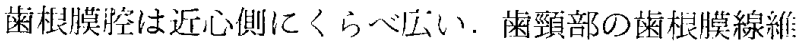
は太く，ほぼ直線的に趁行している。菌根膜け半部から

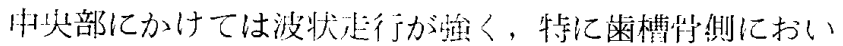

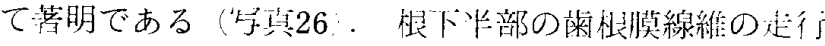
は直線的に斜走し，線維㕱は紃くなっている。

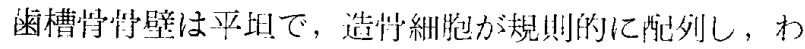
ボかに層状の新牛形をみとめる。

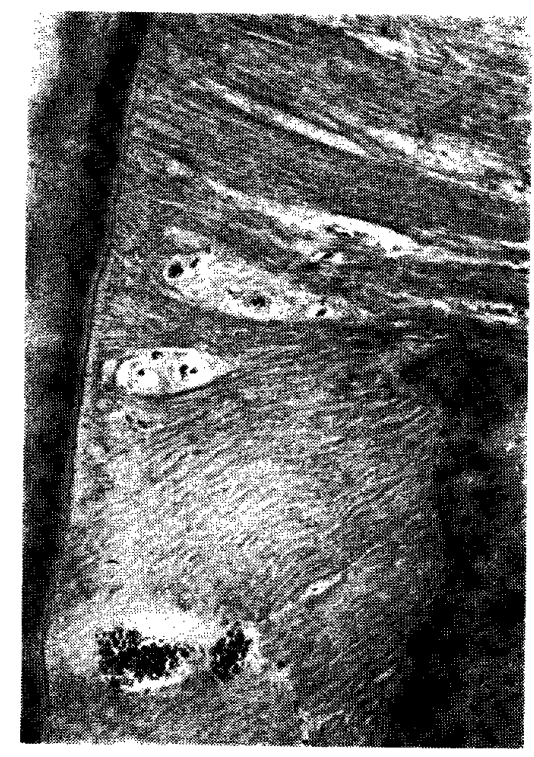

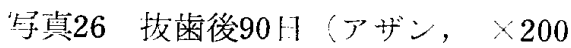

第 2 大白莱遠心根遠心側蒾根膜

120 日所兒

\section{I 抜菌简所光}

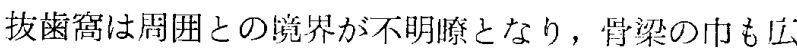

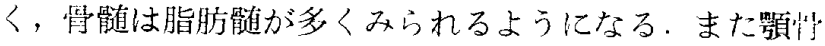
の䎡骵に藷変はみられない。

II 第 2 小田䨑および周囲組織所見 歯牙硬組織に著変はみられない。

1. 遠心根周围組織所㝴

a . 遠心㒋

雪根膜線維束はやや細くなり，規則的な配列がみられ
る。また線維は全体的に波状在舆している。

$$
\text { b . 近心側 }
$$

橉根膜線維は90日所見にくらべ綝く，にるやかな被状

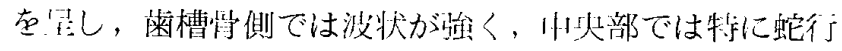
が萻しい(写真27

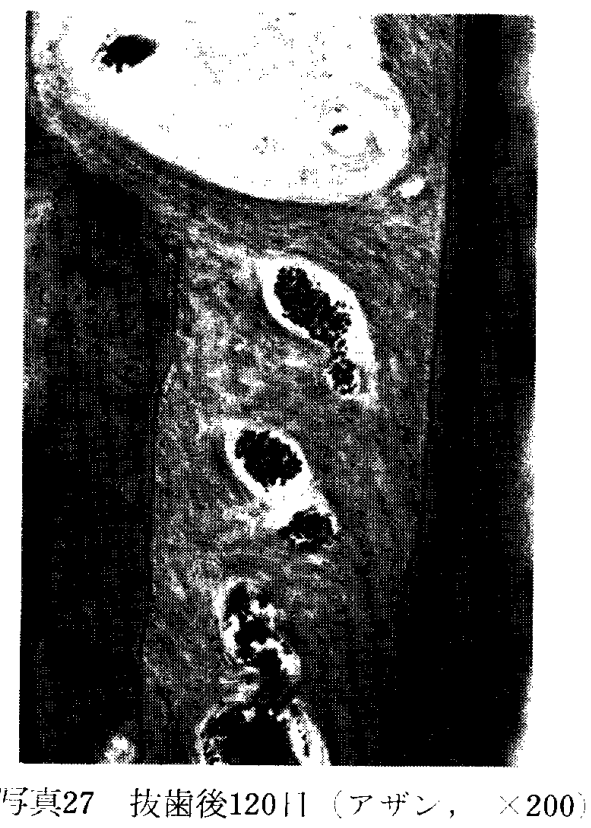

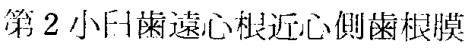

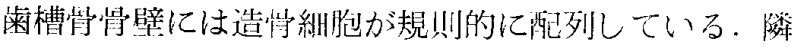

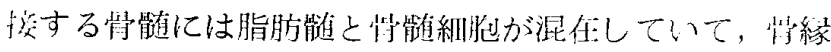
には造学絒胞をみとめる。

2. 近心根均明組織沂见

\section{a . 遠心側}

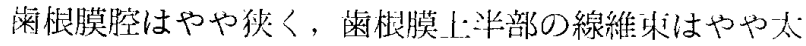
く，直線的な走行を呈している(宁具28)。また根下半

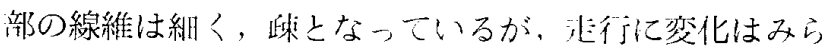
れない。

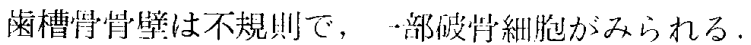

$$
\text { b. 近心側 }
$$

雨根膜腔はやや妄く，歯根膜上半部の線維は隶槽高側 で著しい波状を号している。蒾根膜下半部ではセメント

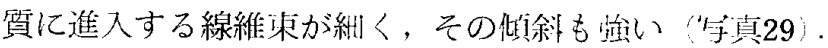

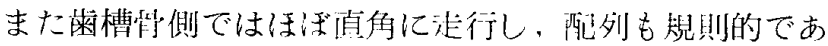
万.

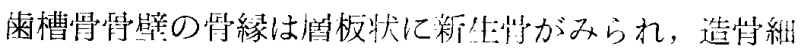
胞が規則正しく㱩列している。

III 第 2 大目菌间囲組織所罗

柬牙は第 2 小四雪と同様に変化はみら扎ない。

1. 近心根周囲組織沂昆 


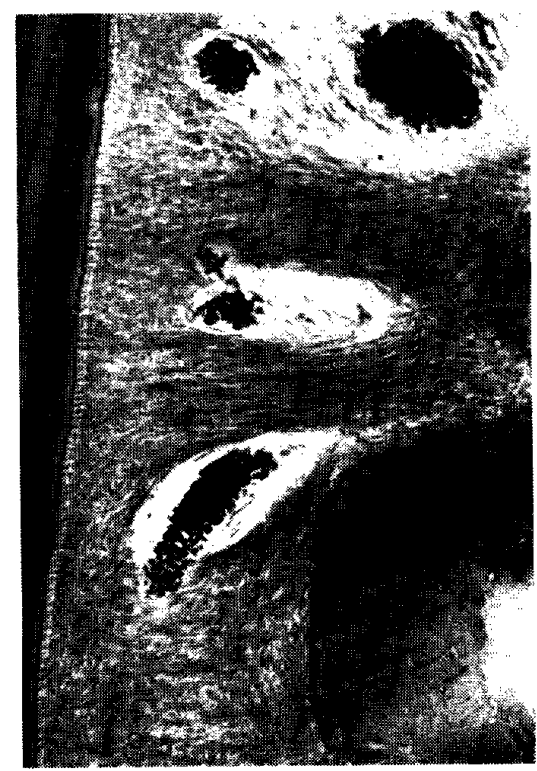

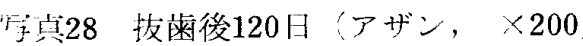

第 2 小国菊近心根遠心側菌根膜

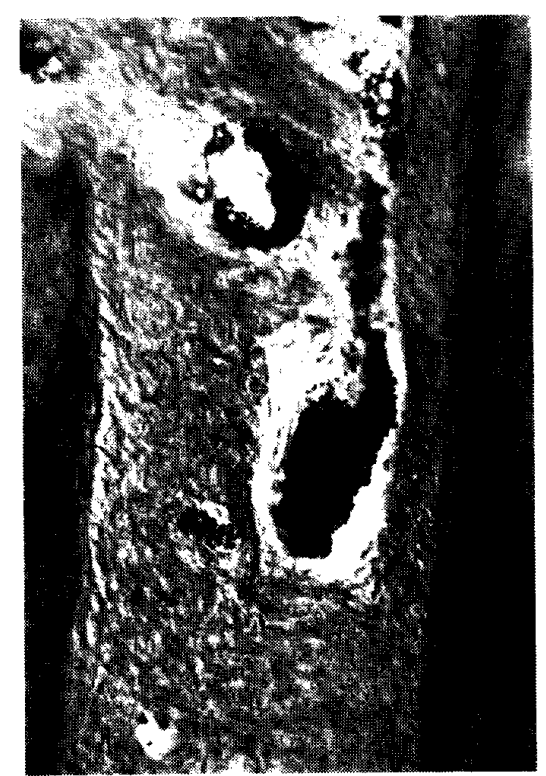

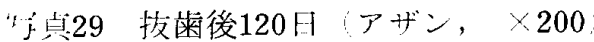

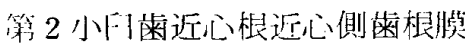

a . 近心側

蒾根膜腔の币には多化はみられない，栄根膜上半部の 歯根膜線維は没状过行を旱しているが，線維束は規則的 に配列している。しかし，根下叫部では波状が猡しく， その进行は不規剘である明真30。

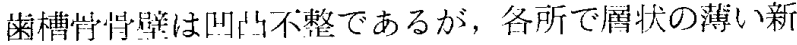
持骨在み上め，造等紐胞が規則的に配外している。

\section{b . 邀心俱}

粜根膜線維は90H所見と変化はみられないが，歯槽州 側の線維束はセメント質側にくらべ太く踈である。

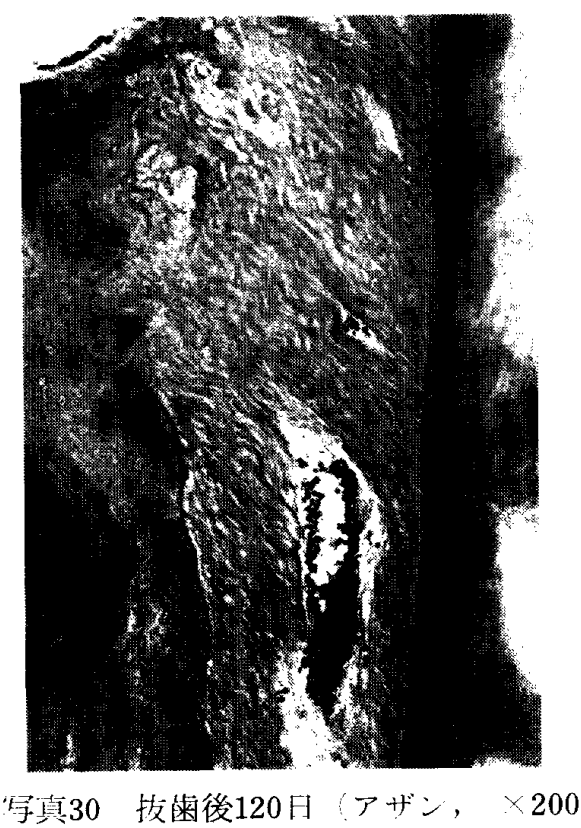

第 2 大F菌近心根近心側菌根膜

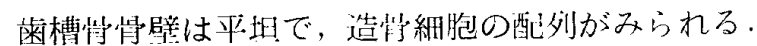

2. 逗心根周用組織所見

a . 近心側

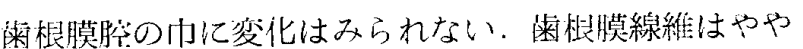
綝く，起行が不規則となっている。

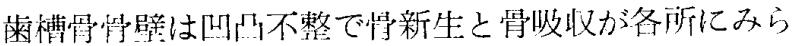
れる。

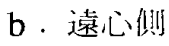

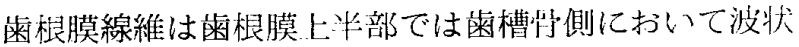
が著しい。また雨根膜下方に行くにしたがい全体的に波

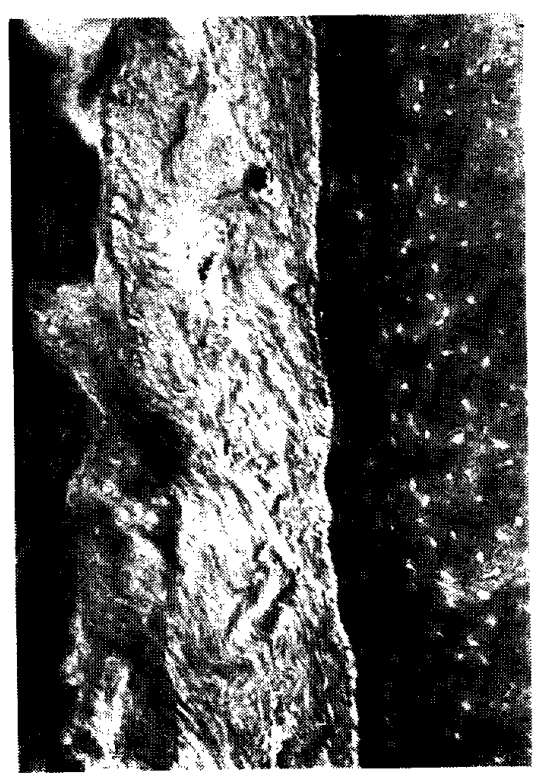

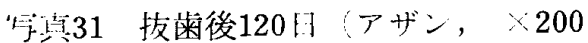
第 2 大F柬遠心根遠心側曾根膜 
状在字するようになる。線維束は雨槽訬側の方が太く， 煉となっているい点 31 。

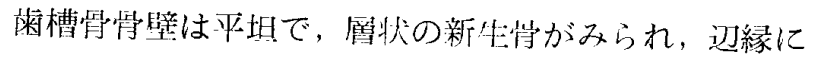
は造省紐胞が規則的に配列している。

\section{総括ならびに考察}

雨牙火損後の雨隣在雨をゆ心とした周四組織の変化に つて病理組織学的に検索を加えたところ前述のような

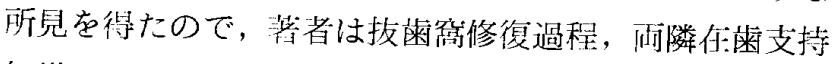
組織および周囲組織の変化について考察を加えた。

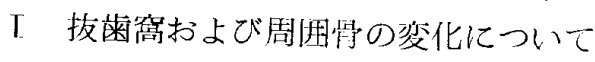

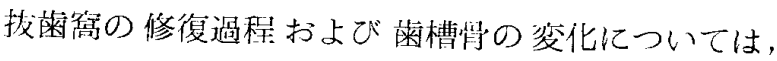

Euler 1923 'が動物で政常拔歯㓣の治療過程につい て痛理組織学的に検索し, 龍行して以来多くの呼究者に よって研究され，一般的には次の上うな経過をたよ゙る上 されている。

すなわち, 鼠初, 拔菌窩は血䭝で满される。次に，拔 歯後 2 日頃より肉芽組織により任餅が器質化され，これ

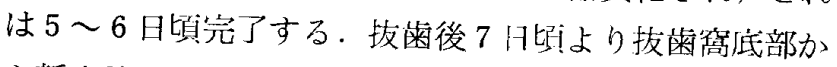
ら新生䯚が形战され，因芽組織は新生情により置きかえ

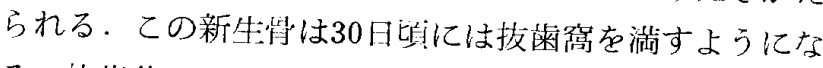
る.技歯後150日頃までに抜歯筒内部は骨の改造が起り， 周囲歯槽骨之構造:ヒほとんど区別できなくなる。

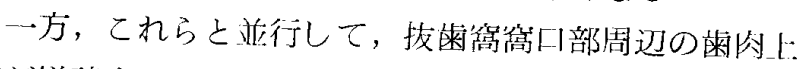
皮が増殖するが，てれは拔歯後 2 日比よりはじまり，20 日すぎには浻口部を被覆するようになる。

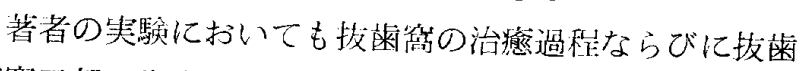
窝䆚口部の歯肉上皮の形成はほぼ同様な経過をたどって いる。

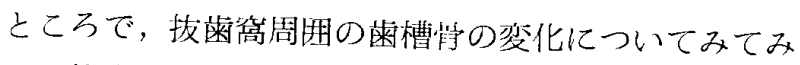

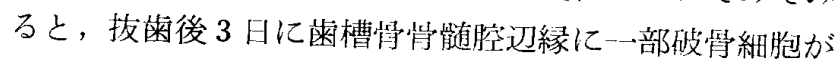
みられ，拔茵後 7 月には蒾槽頂部の肖吸収は著明とな る。しかし，根中間部より下顎骨下緣にかけて，等縁に 多数の造学細胞の配列がみられ，特に根尖端周辺および

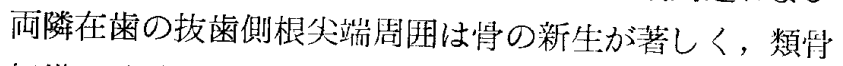

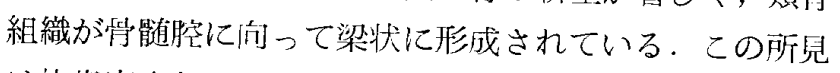
は拔䨑窩底部よりも著しい，また，拔蔽窝に相当する範 囲の下顎骨下縁には多数の造骨紐胞が配列し, 類学組織

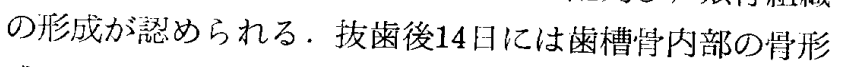
成はさらにさかんで，その範囲も雨隣在菌周囲にまでお よび，拔篓简内の省形成よりも著しい。また，下罰骨卜 縁部に形成された新生骨も抜歯後 7 日よりその币を增し ている，抜菌後 30 日には歯槽学内部の骨形成は抜歯後 14
11に比バ少り，造行䋖胞の数も战少している。また，ト

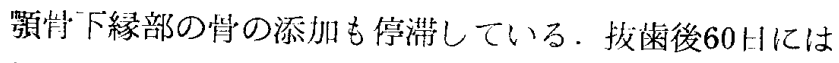

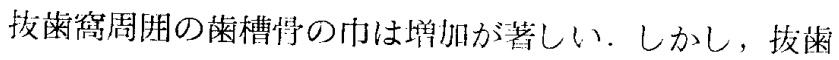

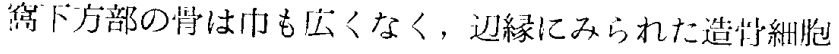
の数も減少が著しく, 恃の改造がみられ, 以後 120 日ま

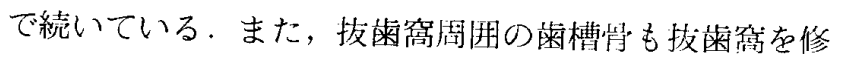
得した新生崖之次第に境界不明となり，政造が行なわれ ている。

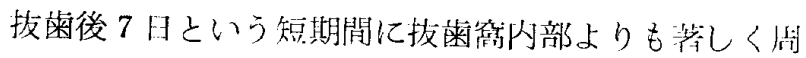
囲歯槽尚の内部で留形成がさかんとなる所兒は，河涼 $1960)^{11}$ ， Boyne (1966 12)，大野 1973:13)，千茠 1976 2`などが報等している。

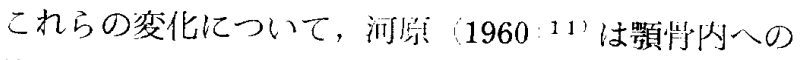
感染を防禦遮断し，種々の外来刺激に刘芯する頻学の抵 抗の現われであろうと述べている。また，大野 1973

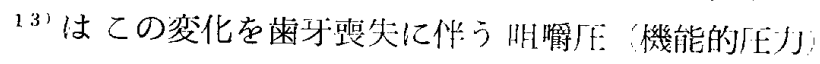

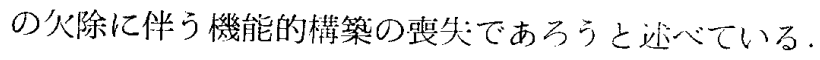

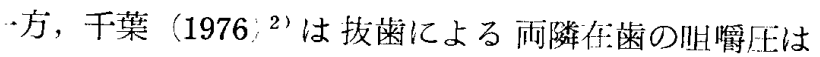

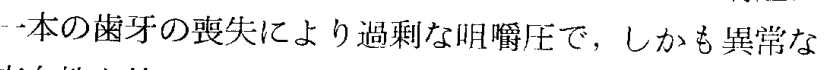
方向性を持った stress が加わる。ささらにその上，抜蒾 綗にも直接 stress が加わる。このことから，䀧常なお

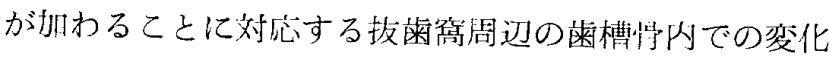
と考えている。

著者は，乙の所兒に対して，大野 $(1973)^{13}$ ， 下䌸

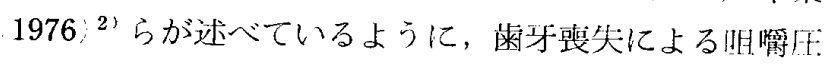

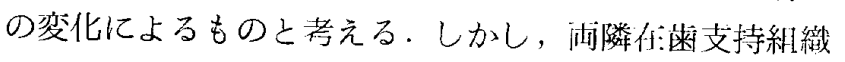
の変化がわずかであることからすれば，一歯火如による

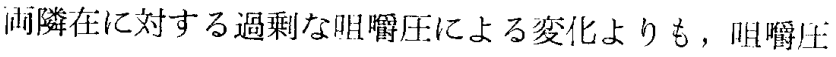
の扣わる方向に異常が生じた事の方が重要だと考えてい る.

また，下顎能下縁部の怗変化については，河原 1960 ，

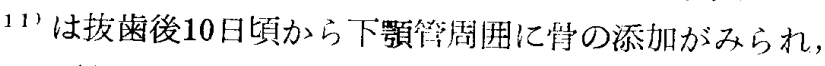

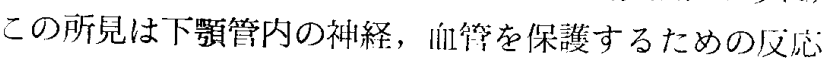
と过べている．また干葉 $(1976)^{2}$ は拔㐘後 3 日より 40

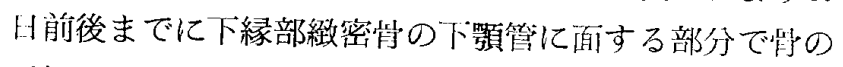
添加が活発で，その後停洼するが吸収されず残仔してい ると派旨している。しかし，これに対する見解は述べら れていない。

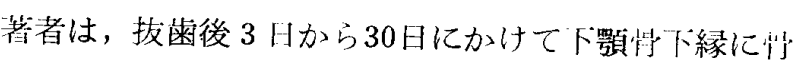
の添加が起る所見を得ている。これは，河原 1960$)^{11) ， ~}$ 干㷊 (1976） ${ }^{2}$ の所見に類似したもの子考えている。猿 の場合，下顎管は周囲を留質によって用まれておらず，

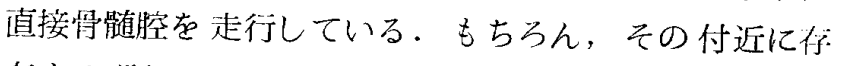
在する骨梁には肖の添加がみられるのであるが, 河原 


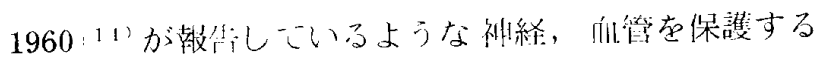
ための汶芯とは䍐われないまま，猿の菌牙は根が文

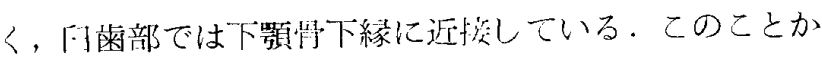

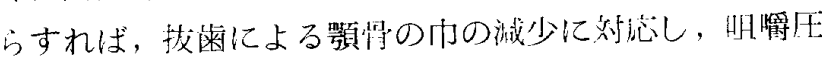

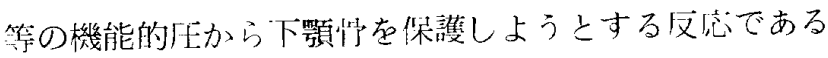
上考える。

II 闲㱛仕料牙支持組織の変化について

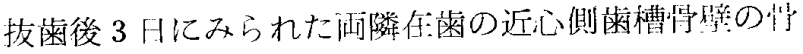

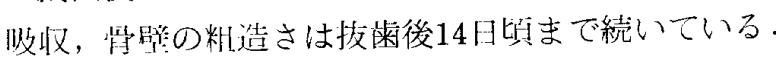

この澵罗は，报茵後の一時期までは生理的雪牙移動に よる変化であると思われる。牛理的匊牙移動が起る㙨罣 についてはいくつかの執版あり 14-28，また，動物に 上って移動方间毛琵っている14,22,29,30!。この中で， 猿の生理的雪牙移動は近心方田であると泟心゙られている 14) ことからも㹬明される。

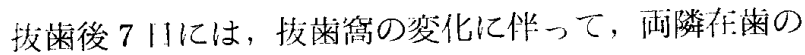

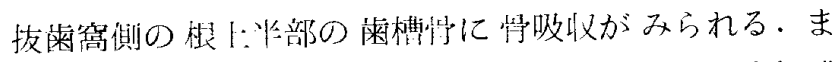

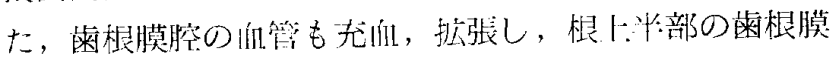

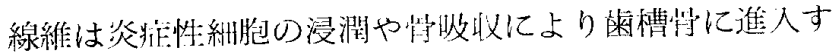

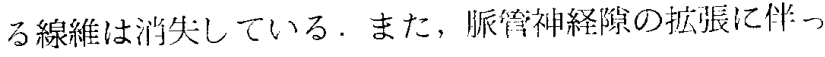
て雪根膜線維の圭行が霜桹膜側で小波状存军している。

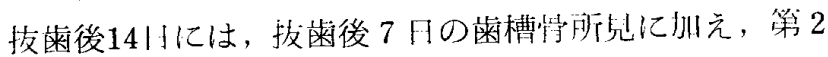

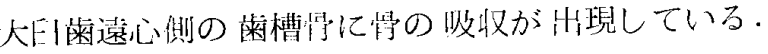

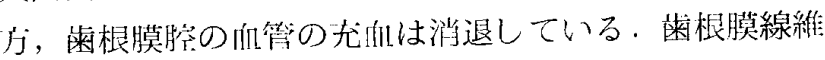

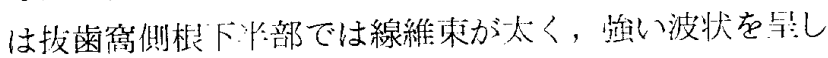

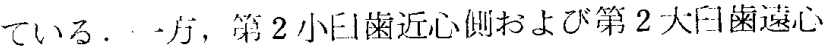

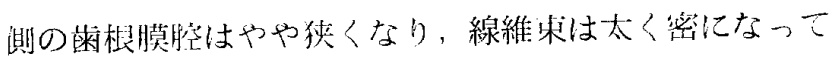
いる。

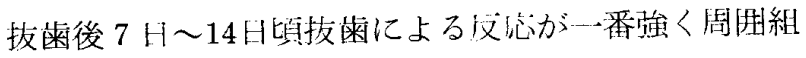
織へ波及した時期と思われる。これは千琹 $1976{ }^{2}$ が

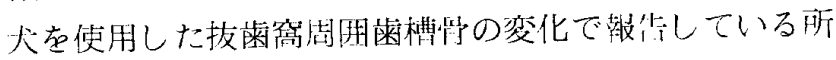
胃に類似している。

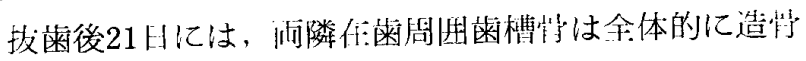

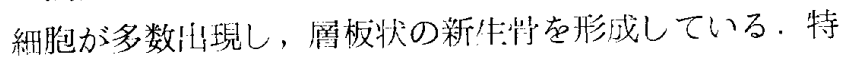
に，根行岐部の崔添打は岁明である。また，歯根膜線維 束は太く，涪蓜列するが，場所によっては，ての尘行 が波状を号している。この特みられる蔝根膜線維束は太 いが寻々しい所見を占している。

この所見は抜歯筒および周囲維織の変化の真で考祭し た界用歯槽少以部の收造過程のひとつであると考える。

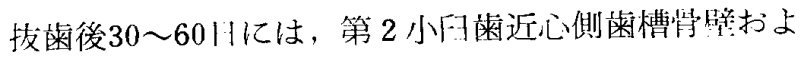

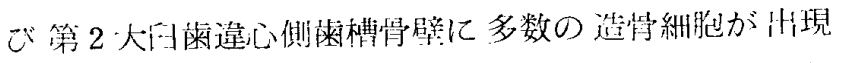
し，部では篔状の新牛骨の添加がみられるようにな

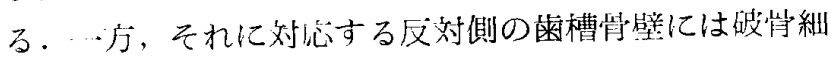

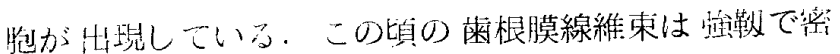

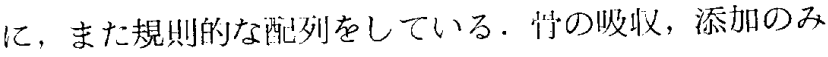

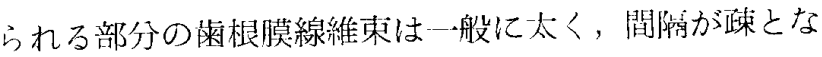
っている。闻者の珙なるところは骨添师の部分で歯根膜 線維の配列が規則的で，峠吸收の部分で配列および束の 太さが不規埧となっていることである。

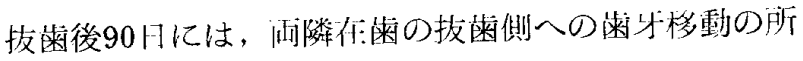
見が諗められるようになる。すなわち，第2 小印歯遠心

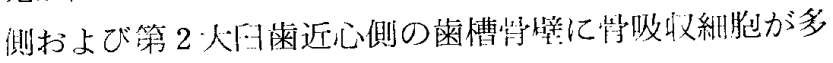

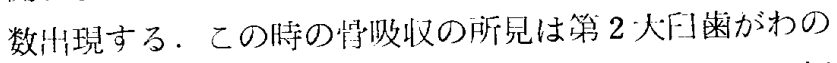

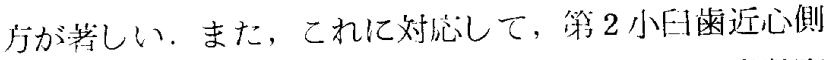

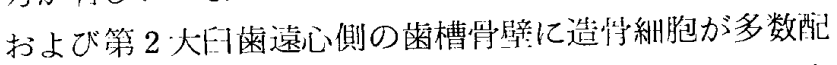

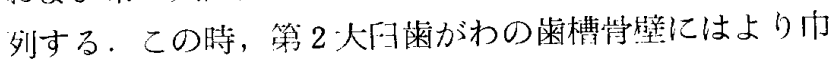
目い粗状の新牛背の添师がみられる。

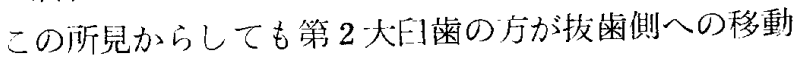
が著しいことがうかがえる。

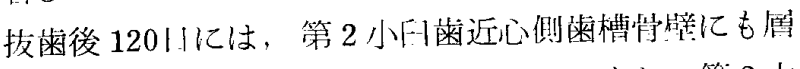
状の新牛省の添扣がみられるようになる。また，算 2 人

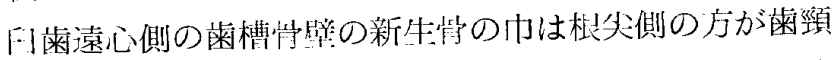

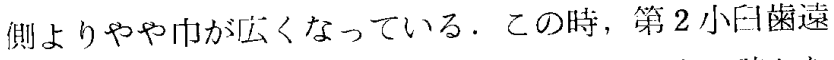

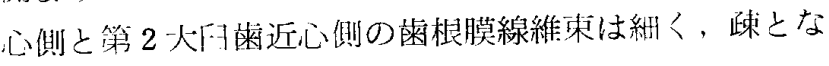
り，波状走行を帠:するようになる。

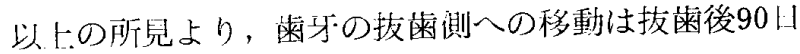

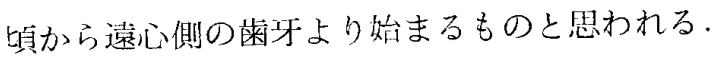

このことは，水谷 $19744^{4)}$ が類似の契駰在行い，们

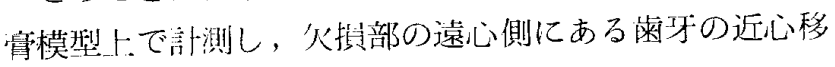
動の汪うが，近心にある嵙牙の遠心移動よりも大きい之 いう見解に・致する。

では，何故に火椇部より遠心側の柬乎の方が移動が大 きいかというと，乙れに対する的碓な論文は何らみられ ないが，䨑の移動施问に関する論文31’の中で Stein and Weinmannはヒトの函は全生涯を通じて徐々で はあるがたえず近心に闻かって移動し続けると論じてい ろ.サルは Baume and Becks (1950 14)が述べてい るように近心移動を行なっているわけだから，この理論 に類似する.さらに, Godon の理論により, 第 2 大El

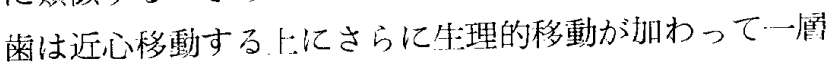

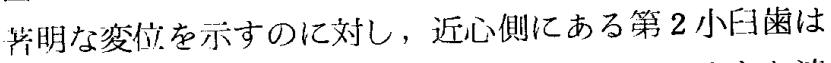
遠心移動が牛理的移動によって相殺されるため大きな遠 心移動を亦さないことになるものと思われる。

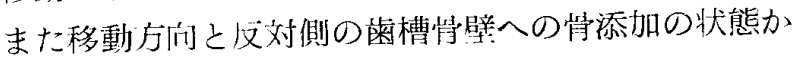
らして，雨牙移動の栐式は歯体移動であると思われる。

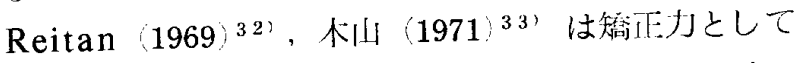
呵いうを作用させた方が歯体移動を起させやすい上述心゙ 
ている。また，堀田(1979:34)は生理的䨑牙移動の奏騃 で牛理的な条件での力の溞さや加わり方は，その意味で かなり緩徐で, 歯体移琵在起こさせるのに適当であった と述べている。

著者の㬰験では，歯牙火掑による朋嚼圧の変化はある

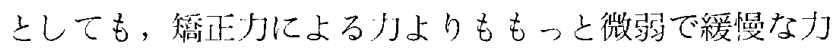
であることからして，本寒験の歯牙移動の様式は柬体移 動であると考える。

さらに，光井ら $19522^{5}$ ， 一総 $\left.(1955,1956)^{6}\right)^{7}$, 富

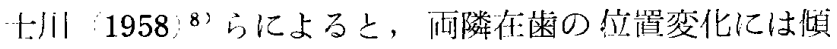
斜のほかに捻転がみられると述べている。

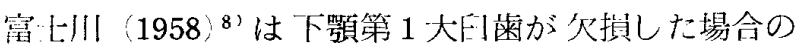
各蒾の柬冠傾斜角度および捻転的度が正常倪とどの程度

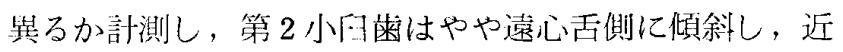
心绪しく捻転する。末た，第 2 大「雬はやや舌側に傾 斜，近心に捻転し著しく近心仳斜していると述心゙てい る。

著者の尖駼から捻軽に刘する明確な所岂は得られてい ないのであるが, 菌根膜線維の変化に若十:をれが現われ ているともいえる。すなわち, 抜歯後 90 日所見で, 啬根 膜上半部の菌根膜線維は第 2 小四迷では近心側, 第 2 大 回粜では遠心側で直線的な走行を冧しており，求根膜下

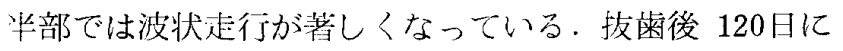
おいても類似の所見を得ている。この所見は捻転による ものとも思われるが，歯牙水平断面所見がないため明碓 にすることはできない。

さて，歯牙欠損による雨隣在霜および周囲組織の変化 の中で朄根膜線維の変化についてみてみると, 菌根膜の 血管の允血, 抁張, 䨑槽管の吸収, 添加に伴ってみられ る雪根膜線維の歯槽骨內進入の消失, 再牛, 線維束の太 さの変化, 走行の変化などの所見を得ている. 特に, 歯 根膜線維の変化は雪槽骨側で著しい。

夹根膜線維の変化の中で, 僑过少による歯牙移動を起 させた時にみられる線維の硝子様変性３２３３３３５（は何ら

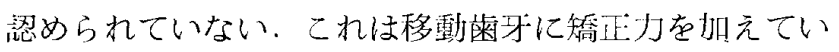
ないために起らなかったものと思われる。しかし，畨可 移動に伴う移動側の歯根膜の圧迫はみられ，雪根膜䧑の 门の変化と線維の波状走行が所罗として得られている. 線維束の太さの変化は菌槽脂の忣収した部分に新生常が 添加し, 雨根膜線維后封入する際に太心線維がみられ る。

秋吉 $19493^{36}$ はシャーヒー一線維の霜槽岗に抢ける機 能的機械的影響のなかで, 㐘牙に刘する辛引漒く作用 する部分では歯槽骨の貫膜面には多数の太いシャャーピー
線雜が附清しており，率当りが弱い部位では胃膜面に附 着するシャーピー線維は細くて少ないと述べている。

このことは著者の所見にも散見され，特に，拔蒾後 60 日頃第 2 小巨歯近心側㧈よび第 2 大曰菌遠心側の歯桹膜 線維の配列が密となり, 歯根膜下半部の一部では線維㷊 が太くなっている．拆歯後 120 日には 60 日に比心配列は やや踈となり, 線維束の太い部分も少なくなっている.

このととから前述した雬槽咢の変化とあわせ考える 之, 活隣在菌に抜料側への移動の才が打わり，その反応

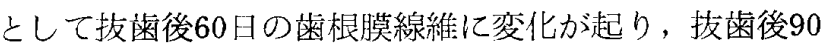

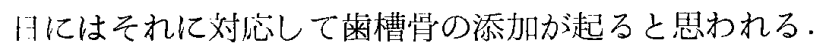

ところで，歯根膜線維は Sicher and Bhashar (19

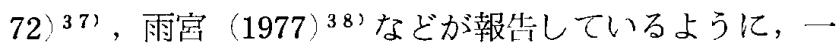
端をセメント質に，他端を歯槽骨に封入されているが， 主線維を構成する個々の膠原小線維はその全長にわたっ

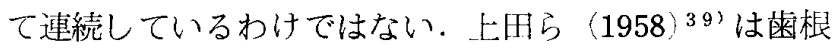
膜線維を電子顕微鏡にて観察し, 蒾槽骨とセメント質の 閒に展张される線維は一本一本が連続性のあるものでは なく，两側から派生した線維が中間叢でからみあってい るということで歯の萌出, 挺出, 移動などの可能性が説 明されると述べている。

雨営 $(1977)^{38 ;}$ は歯根膜線維の代謝はその機能と密接 に関係し，この時の変化はおもに歯根膜中央部より囦槽 肖側に見られ，セメント質に封入されている線維の変化 は軽度であると述べている。

このことからすれば，箸者の所罗にみられる歯根膜柬 槽等側での変化は説明できる。また，雨营 $(1977)^{38}$ 'が

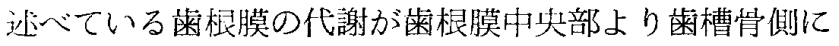
あるという見解に一致する。

\section{結論}

著者はカニクイザルを使用し，畨牙火損による両隣在: 匊の周囲組織の変化について病理組織学的に検索し次の ような結果を得た。

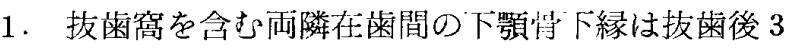
け〜30日に骨の添加がみられる。

2. 生理的歯牙移動による両隣在㐘の近心側崡槽骨壁 の粗造並びに骨吸収は抜歯後14日頃まで続いている.

3. 技歯による耐䑝在歯周团組織の変化は抜歯後 7 日 に第 2 小F歯遠心側歯槽骨壁の骨吸収並びに第 2 大巨歯 近心側崡槽骨壁に以前より著しい等吸収が起る。

4. 抜䨑後21日には両隣在歯の周围雪槽骨壁に肖の添 加がみられる。この時期には生理的菌牙移動の所見はみ 
られない。

5. 抜雨後30日〜 60 日には第 2 小曰幽近心側および第 2 大曰雪遠心側雬槽骨壁に多数の造骨細胞が出現し，- . 部では層状の新生待の添加がみられ，てれに対応する側 の蒾槽骨壁には破骨細胞が出現している。また，歯根膜 線維は骨の忣収部では線維束の配列および太さが不規則 で，带の添加部では線維束が太く，規則的に配列してい る.

6. 抜蒾後 90 日には第 2 小罒歯近心側，第 2 大曰菌遠 心側雪槽骨壁に層状の新生骨が形成され，霜根膜線維は 第 2 小曰歯近心側，第 2 大曰歯遠心側の雬根膜上半部で 直線的走行を，雪根膜下半部では波状走行が著しくなっ ている。

7. 両隣在菌の拔歯側への移動は技歯後90日頃が顕著

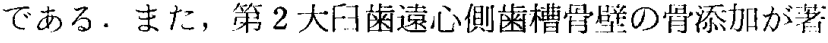
しいことから，歯牙移勳は第 2 大印歯の方が著明であ 万.

8. 夹牙の抜蒾側への移動様式は粜体移動である.

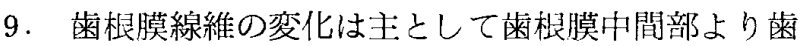
槽骨側で起っている。

稿を終るに臨み, 本研究に終始御愁切なる御指導, 御 校閲を賜わった九州霜科大学第一日腔外科学教室山且長

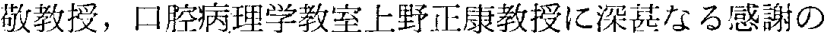
意を表します。また終始変ら仅御教示と御鞭搱を戴きま した福田仁一博士に深謝します。

あわせて，種々の御協力を戴きました第一日腔外科学 教公員各位に感謝します。

\section{引用 文献}

1) Euler, H. : Die Heilung von Extraktionswunden, Dtsch. Mschr. f. Zahnheilk. 24:685-$700,1923$.

2 ）千葉博茂：歯牙抜法につづく歯槽骨変化のラバリング法とマイクロラジオグラフィによる研究，歯基礎誌 $18: 1-52,1976$.

3) 村田睦男：抜歯後歯槽骨の変化に関する補経学的研究，口科誌 $14: 204-213,1965$.

4 ) 水谷 紘：菌牙欠損後の顎堤の形態変化ならびに残存歯の位置変化, 補緅誌 $17: 275-296,1974$.

5：光井敏郎・核井襄二：補緅学上から観た顔面並びに顎の研究, 其の三, 歯牙丧失後に於ける残存椈の移動に 就いて, 㐘科突学 $15: 52$ - 56,1952 .

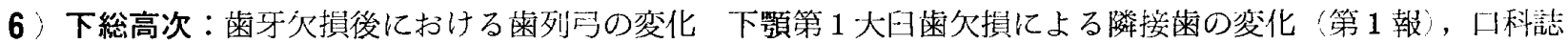
$4: 256,1955$.

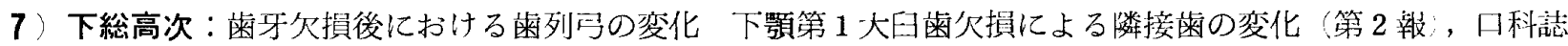
$5: 311-312,1956$.

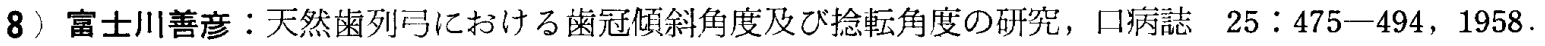

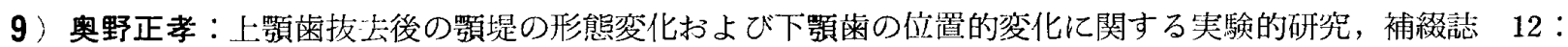
$308-336,1968$.

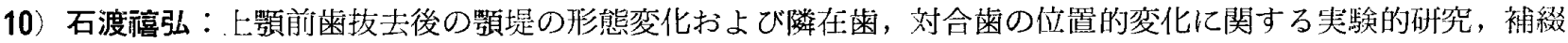
誌 $16: 293-320,1973$.

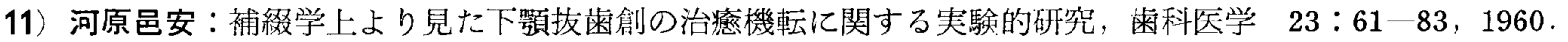

12 Boyne, P. J. : Osseus repair of the postextraction alveolus in man, Oral Surg. 21:805$813,1966$.

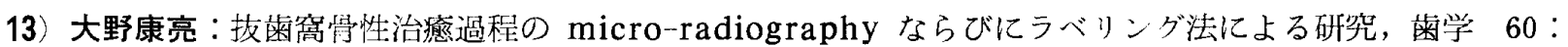
$839-868,1973$.

14) Baume, L. J. and Becks, H. : The development of the dentition of Macaca mulatta, Am. J. Orthod. $36: 723-748,1950$.

15) Schneider, B. and Sicher, H. : Physiologic migration of anterior teeth, Angle Orthod. $28: 166-175,1958$.

16) Murphey, T. : Compensatory mechanisms in facial height adjustment to functional tooth 
attrition, Aust. Dent. J. $4: 312-323,1959$.

17) Moss, J. P. and Picton, D. C. A. : Experimental mesial drift in adult monkeys (Macaca irus), Arch. Oral Biol. 12:1313-1320, 1967.

18 Kronman, J. H. : Tissue reaction and recovery following oxperimental tooth movement, Angle Orthod. $41: 125-132,1971$.

19) Brodie, A. G.: The significance of tooth form, Angle Orthod. $4: 335-350,1934$.

20 Brodie, A. G. : The significance of tooth form, Angle. Orthod. 5:41-54, 1935.

21 Lear, C. S. C., Catz, J., et al. : Measurement of lateral muscle forces on the dental arches, Arch. Oral Biol. 10:669-689, 1965.

22 Sicher, H. and Weinmann, J. P. : Bone growth and physiologic tooth movement, Am. J. Orthod. Oral Sury. 30:109-132, 1944 .

23 Brash, J. C. : The growth of the alveolar bone and its relation to the movements of the teeth, including eruption, Int. J. Orthod. Oral Surg. Radiog. $14: 196-223,283-293$, $398-405,487-504,1928$.

24: Hoffman, M. M. and Schour, I. : Quantitative studies in the development of the rat molar, Am. J. Orthod Oral Surg. 26:854-874, 1940.

25 Biggerstaff, R. H. : The anterior migration of dentitions and anterior crowding, Angle Orthod. $37: 227-240,1967$.

26 Thompson, H. E., Myers, H. I., et al. : Preliminary macroscopic observations concerning the potentiality of supra-alveolar collagenous fibers in orthodontics, Am. J. Orthod. $44: 485-497,1958$.

27 Picton, D. C. A. and Moss, J. P. : The part played by the trans-septal fiber system in experimental approximal drift of the cheek teeth of monkeys (Macaca irus), Arch. Oral Biol. $18: 669-680,1973$.

28 Moss, J. P. and Picton, D. C. A. : The effect on approximal drift of cheek teeth of dividing mandibular molars of adult monkeys (Macaca irus), Arch. Oral Biol. 19: 1911 $-1214,1974$.

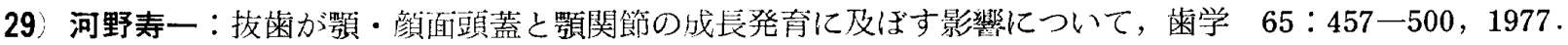

30) Myer, H. I. and Wyatt, W. P. : Some histopathologic changes in the hamster as the result of a continuously acting orthodontic appliance, J. Dent. Res. $40: 846-856,1961$.

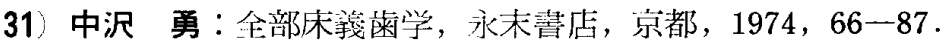

32 Reitan, K. : Biomechanical principles and reactions, current orthodontic concepts and techniques, Saunders, Philadelphia. 1969, 56-159.

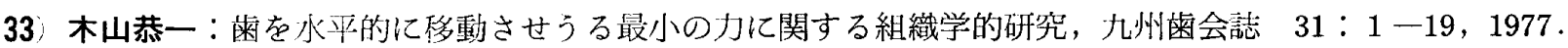

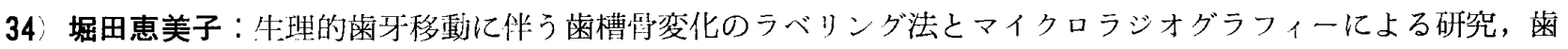
基礎誌 $21: 433-461 ， 1979$.

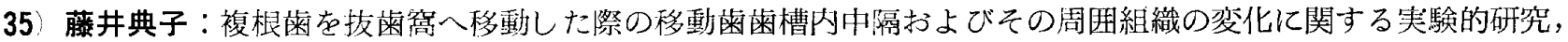
㐘科垁品 $35: 209-235,1972$.

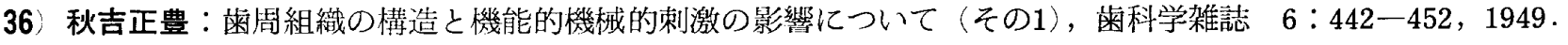

37) Sicher, H. and Bhasker, S. N. : Orban's oral histology and embryology. Mosby, Saint Louis, 1972, 206-233.

38 雨宮 㻔：ヘリオドンティックスの臨床，医菌蒋出版，東京，1977，1-17.

39）上田雅俊・他：南肉線維㧈よび菌根膜線維の走查型電子顕微鏡による観察所見，日菌周誌 $20: 157 一 164$, 1958 . 